\title{
One-year observations of size distribution characteristics of major aerosol constituents at a coastal receptor site in Hong Kong - Part 1: Inorganic ions and oxalate
}

\author{
Q. Bian ${ }^{1, *}$, X. H. H. Huang ${ }^{2}$, and J. Z. Yu ${ }^{1,2}$ \\ ${ }^{1}$ Department of Chemistry, Hong Kong University of Science \& Technology, Clear Water Bay, Kowloon, Hong Kong \\ ${ }^{2}$ Institute of the Environment, Hong Kong University of Science \& Technology, Clear Water Bay, Kowloon, Hong Kong \\ "now at: Department of Atmospheric Science, Colorado State University, Fort Collins, CO, USA
}

Correspondence to: J. Z. Yu (jian.yu@ust.hk)

Received: 13 November 2013 - Published in Atmos. Chem. Phys. Discuss.: 17 January 2014

Revised: 19 July 2014 - Accepted: 21 July 2014 - Published: 2 September 2014

\begin{abstract}
Size distribution data of major aerosol constituents are essential in source apportioning of visibility degradation, testing and verification of air quality models incorporating aerosols. We report here 1-year observations of mass size distributions of major inorganic ions (sulfate, nitrate, chloride, ammonium, sodium, potassium, magnesium and calcium) and oxalate at a coastal suburban receptor site in Hong Kong, China. A total of 43 sets of size-segregated samples in the size range of $0.056-18 \mu \mathrm{m}$ were collected from March 2011 to February 2012. The size distributions of sulfate, ammonium, potassium and oxalate were characterized by a dominant droplet mode with a mass mean aerodynamic diameter (MMAD) in the range of $\sim 0.7-0.9 \mu \mathrm{m}$. Oxalate had a slightly larger MMAD than sulfate on days with temperatures above $22^{\circ} \mathrm{C}$ as a result of the process of volatilization and repartitioning. Nitrate was mostly dominated by the coarse mode but enhanced presence in fine mode was detected on winter days with lower temperature and lower concentrations of sea salt and soil particles. This data set reveals an inversely proportional relationship between the fraction of nitrate in the fine mode and product of the sum of sodium and calcium in equivalent concentrations and the dissociation constant of ammonium nitrate (i.e., $\left(1 /\left(\left[\mathrm{Na}^{+}\right]+2\left[\mathrm{Ca}^{2+}\right]\right) \times\left(1 / K_{e}^{\prime}\right)\right)$ when $P_{\mathrm{n}_{-} \text {fine }}$ is significant (> 10\%). The seasonal variation observed for sea salt aerosol abundance, with lower values in summer and winter, is possibly linked with the lower marine salinities in these two seasons.
\end{abstract}

Positive matrix factorization was applied to estimate the relative contributions of local formation and transport to the observed ambient sulfate level through the use of the combined data sets of size-segregated sulfate and select gaseous air pollutants. On average, the regional/super-regional transport of air pollutants was the dominant source at this receptor site, especially on high-sulfate days while local formation processes contributed approximately $30 \%$ of the total sulfate. This work provides field-measurement-based evidence important for understanding both local photochemistry and regional/super-regional transport in order to properly simulate sulfate aerosols in air quality models.

\section{Introduction}

The size distribution of aerosols records information of sources and atmospheric processing of particulates. These characteristics of atmospheric particles directly influence local visibility and regional radiative forcing. Substantial knowledge has been gained on the size distributions of the major inorganic ions, elemental carbon (EC) and organic carbon (OC), in the past decade in Hong Kong (HK) and over the adjacent Pearl River delta (PRD) region in southern China (Zhuang et al., 1999a, b; Yao et al., 2003; Huang et al., 2006; Liu et al., 2008; Yu et al., 2010; Lan et al., 2011). The major species, including sulfate, ammonium, OC and EC, predominantly resided in the droplet mode with mass mean aerodynamic diameters (MMAD) in the range of 
$0.56-1.0 \mu \mathrm{m}$ over this region while nitrate was often observed to have a dominant presence in the coarse mode $(>3.2 \mu \mathrm{m})$ over the coastal areas. In these past studies, however, there is a lack of concurrent measurements of other data (e.g., gaseous data) (Zhuang et al., 1999b; Huang et al., 2006; Yu et al., 2010; Lan et al., 2011) or only a short period was covered; e.g., the PRIDE-PRD (Program of Regional Integrated Experiments of Air Quality over Pearl River Delta) campaign 2004 and 2006 during summer (Liu et al., 2008; Yue et al., 2010). In this work, size-segregated aerosol major constituent data, together with integrated and comprehensive observations of gaseous and bulk particulate pollutants, were obtained for 1-year, from March 2011 to February 2012 at the Air Quality Research Supersite (http://envr.ust.hk/research/ research-facility/background-materials.html) of the Hong Kong University of Science and Technology (HKUST). The comprehensive data set significantly improves the data utility and data interpretation as compared with those in previous size distribution studies. As it will be demonstrated later in this paper, the measurements of a number of gaseous and particulate matter (PM) pollutants (e.g., $\mathrm{CO}, \mathrm{SO}_{2}, \mathrm{O}_{3}, \mathrm{PM}_{2.5}$, etc.) at the same site provide supplementary information for a more in-depth understanding of aerosol sources and processing.

Much of this work's focus is on sulfate and nitrate. Sulfate remains a top contributor to aerosols over the PRD region (He et al., 2011; Huang et al., 2014a), although a consensus on $\mathrm{SO}_{2}$ emission reduction was reached between the Hong Kong SAR Government and the Guangdong Provincial Government in 2002 (http://www.epd.gov.hk/epd/english/environmentinhk/air/ prob_solutions/strategies_apc.html\#point_1). This arouses the interest in determining the relative contributions of local formation versus regional/super-regional transport to the observed ambient sulfate loadings. A number of numerical modeling approaches (e.g., observational-based models and source-oriented models) have been applied to identify the source origins of sulfate over this region (Zhang et al., 2012; Wu, 2013; Xue et al., 2014). The accuracy of the results from these numerical studies heavily relies on whether the emission inventory and meteorological dynamics are properly represented in the models. In this work we attempt to use field measurements of size-segregated chemical composition data and select gaseous pollutants coupled with receptor modeling to estimate local formation vs. transport contributions.

Nitrate is a significant, although less abundant than sulfate, component of $\mathrm{PM}_{2.5}$. It also often has abundant presence in the coarse particles. A source analysis study by Yuan et al. (2013) using receptor modeling of nearly 10-year speciated $\mathrm{PM}_{10}$ data found secondary nitrate in $\mathrm{PM}_{10}$ increased by $30 \%$ from 1998 to 2007 in HK while a decreasing contribution from vehicle emissions was observed. It is observed that the improvement due to reductions of PM in local emissions has been offset by an increase in nonlocal contributions with nitrate being a major species. Yang et al. (2011) reported a higher $\left[\mathrm{NO}_{3}^{-}\right] /\left[\mathrm{SO}_{4}^{2-}\right]$ ratio in $\mathrm{PM}_{2.5}$ in Guangzhou than in other cities in China and implied that on-road automobiles could be the major contributor. Hence, investigation of the partitioning behaviors of nitrate between coarse and fine modes through size distribution measurements will help to quantify factors and processes affecting $\mathrm{PM}_{2.5}$ nitrate.

The size distribution characterization work reported in this work was conducted at the HKUST supersite. Hong Kong is influenced by contrasting air masses in winter and summer due to the Asian monsoon system. The HKUST supersite is located upwind of HK on the east coast. During most of time in winter the prevailing wind is from north/northeast. In summer, the dominant wind affecting the site is mainly from the South China Sea with a relatively clean air mass. As such, it is an appropriate place to study the influence of air pollution from outside HK. The primary goal of this work is to understand the sources and processing of major ionic aerosol constituents by analyzing their size distribution measurements for a year at this coastal receptor site. The size distribution characteristics of major ionic species are discussed in detail in this paper. The year-long data has enabled us to look into the partitioning behavior of nitrate and the factors affecting its abundance in the fine mode. Attempts were also made to apply positive matrix factorization (PMF) to apportion measured size-segregated sulfate into locally formed and regional sources. EC and OC in these size-segregated samples were also measured. Their size distribution characteristics and the major contributing sources will be reported in a separate paper.

\section{Sampling location and chemical analysis}

A 10-stage Micro-Orifice Uniform Deposit Impactor (MOUDI, nonrotating version, MSP Corp., Shoreview, MN) aerosol sampler was used to collect size-segregated samples with nominal cut sizes of 18 (inlet), 10.0, 5.6, 3.2, $1.8,1.00,0.56,0.32,0.18,0.100$, and $0.056 \mu \mathrm{m}$. The sampler was located at the HKUST Air Quality Research Supersite $\left(22^{\circ} 20^{\prime} 15.72^{\prime \prime} \mathrm{N}, 114^{\circ} 16^{\prime} 3.23^{\prime \prime} \mathrm{E}\right.$; Fig. S1 in the Supplement). The inlet was $\sim 2 \mathrm{~m}$ above the roof $(\sim 14 \mathrm{~m}$ above sea level) and the sampler was operated at a flow rate of $30 \mathrm{~L} \mathrm{~min}^{-1}$. The flow rate was checked before and after every sampling event. The collection substrates were $47 \mathrm{~mm}$ quartz fiber filters, prebaked at $550{ }^{\circ} \mathrm{C}$ overnight before use. Special spacers of 0.05 in. in thickness (MSP Corp., Shoreview, MN) were used between adjacent stages to compensate the shorter jet-to-plate distance due to the thicker quartz filter substrate than aluminum foil, on which characterization of the cutoff size and response factor of each impact stage is based. All the filter samples were stored at $-18^{\circ} \mathrm{C}$ in a refrigerator before analysis. The sampling was carried out for $24 \mathrm{~h}$, from midnight to midnight, every 12 days from 1 March 2011 to 29 February 2012. An additional 12 sets of samples were 
collected on an ad hoc basis to target high-pollution days, including one set in July, three in August, one in September, three in October, one in November, and three in February, respectively. One field blank sample was taken during each sampling event and analyzed in the laboratory together with the samples. The average gravimetric $\mathrm{PM}_{2.5}$ concentration was $25.9 \pm 17.6 \mu \mathrm{g} \mathrm{m}^{-3}$ on the sampling days (Huang et al., 2014a). Among the 12 ad-hoc samples, one sample was collected on 4 August 2012. On this day, relatively low $\mathrm{PM}_{2.5}$ $\left(8.8 \mu \mathrm{g} \mathrm{m}^{-3}\right)$ was recorded, as the predicted influence by the severe typhoon Muifa did not happen. The $\mathrm{PM}_{2.5}$ concentration for the other $11 \mathrm{ad}$ hoc samples ranged from 17.6 to $61.8 \mu \mathrm{g} \mathrm{m}^{-3}$.

The MOUDI samples were analyzed for ionic species. One-quarter of each filter substrate was extracted with $3 \mathrm{~mL}$ of double deionized water in an ultrasonic bath for $30 \mathrm{~min}$ and the extract was left at $4{ }^{\circ} \mathrm{C}$ in a refrigerator overnight to ensure complete extraction. The extracts were filtered using a PTFE (polytetrafluorethylene) syringe filter $(0.45 \mu \mathrm{m}$, Millipore, Billerica, MA, USA) and then analyzed for ionic species using ion chromatography (IC; Dionex DX-500, Thermo Fisher Scientific, MA, USA). The anions (i.e., $\mathrm{Cl}^{-}$, $\mathrm{NO}_{3}^{-}, \mathrm{SO}_{4}^{2-}, \mathrm{C}_{2} \mathrm{O}_{4}^{2-}$ ) were separated using an AS-11 column and a gradient elution solution of $\mathrm{NaOH}$. The cations (i.e., $\mathrm{Na}^{+}, \mathrm{NH}_{4}^{+}, \mathrm{K}^{+}, \mathrm{Mg}^{2+}, \mathrm{Ca}^{2+}$ ) were separated using a CS-12A column and methanesulfoinc acid as the elution solution (Yang et al., 2005). Full calibrations were carried out in every batch of the ionic analysis. The species concentrations were field-blank corrected.

Daily $\mathrm{PM}_{2.5}$ sampling was conducted using a mid-volume sampler equipped with five sampling channels (SASS, Met One Instrument, OR, USA) in the same period. The collection substrates installed in the five channels include one Teflon filter for gravimetric determination of $\mathrm{PM}_{2.5}$ mass and element analysis, one nylon filter preceded by a $\mathrm{MgO}$-coated denuder for IC analysis of ionic species, and three prebaked quartz fibers for $\mathrm{EC}$ and $\mathrm{OC}$ thermal analysis. $\mathrm{PM}_{2.5}$ element data (i.e., silicon) used in this study were obtained from the Teflon filters through analysis using an energy dispersive Xray fluorescence spectrometer (ED-XRF, Epsilon 5, PANalytical, the Netherlands). The analytical details of gravimetric measurements, ionic and XRF analyses of the $\mathrm{PM}_{2.5}$ samples were given in the paper by Huang et al. (2014a).

Criteria gaseous pollutants were measured by various gas analyzers including $\mathrm{SO}_{2}$ (100A, API Inc.), $\mathrm{CO}$ (300A, API Inc.) and $\mathrm{O}_{3}(400 \mathrm{E}$, Teledyne Instruments Inc.) from June 2011 to February 2012. Continuous measurements of inorganic species and their related gas-phase components in the ambient air were provided by a MARGA (Monitor for Reactive Gases and Aerosols; Metrohm Applikon, the Netherlands) (Huang et al., 2014a). Relative humidity (RH), temperature, wind speed and wind direction were recorded by an automatic weather station installed on a $10 \mathrm{~m}$ tower at the site and are shown in Fig. S2 in the Supplement.

\section{Results and discussion}

\subsection{Comparison between MOUDI and PM2.5 measurement}

Ionic species measurements $\left(\mathrm{Cl}^{-}, \mathrm{SO}_{4}^{2-}, \mathrm{NO}_{3}^{-}, \mathrm{C}_{2} \mathrm{O}_{4}^{2-}\right.$, $\mathrm{Na}^{+}, \mathrm{NH}_{4}^{+}, \mathrm{K}^{+}, \mathrm{Mg}^{2+}$, and $\mathrm{Ca}^{2+}$ ) by MOUDI and by the mid-volume $\mathrm{PM}_{2.5}$ sampler were compared in Fig. 1. Concentrations for the ions in individual size bins of up to $3.2 \mu \mathrm{m}$ were added up and compared with those in $\mathrm{PM}_{2.5}$. Good correlations were found between the two sets of measurements for $\mathrm{SO}_{4}^{2-}, \mathrm{Na}^{+}$, and $\mathrm{NH}_{4}^{+}$, with $R^{2}>0.90$ and the slopes in the range of 0.9-1.1. Measurement uncertainties aside, additional factors - such as particle bounce, sample handling, and the different size cut points (i.e., $2.5 \mu \mathrm{m}$ vs. $3.2 \mu \mathrm{m}$ ) - could also contribute to deviation from a unity slope (Stein et al., 1994; Howell et al., 1998; Chang et al., 2000; Duan et al., 2005). $\mathrm{Na}^{+}$was dominated by the coarse mode $(>2.5 \mu \mathrm{m})$ and the amount of $\mathrm{Na}^{+}$in the size range of $2.5-3.2 \mu \mathrm{m}$ could be significant relative to $\mathrm{Na}^{+}$in $\mathrm{PM}_{2.5}$. For the less abundant species (i.e., $\mathrm{C}_{2} \mathrm{O}_{4}^{2-}, \mathrm{K}^{+}$, and $\mathrm{Cl}^{-}$), the correlation between the MOUDI $\left(\mathrm{PM}_{3.2}\right)$ and $\mathrm{PM}_{2.5}$ measurements were still reasonably good $\left(R^{2}>0.6\right) . R^{2}$ values for $\mathrm{Mg}^{2+}$ and $\mathrm{Ca}^{2+}$ were 0.48 and 0.36 , respectively. The weaker correlations than those of $\mathrm{SO}_{4}^{2-}, \mathrm{Na}^{+}$and $\mathrm{NH}_{4}^{+}$could be explained by the larger measurement uncertainties as a result of their much lower concentration levels.

The comparison of nitrate between MOUDI and $\mathrm{PM}_{2.5}$ measurements indicates undersampling by MOUDI (Fig. 1), which is an expected result of the semi-volatile nature of nitrate. The volatile loss of particulate nitrate is anticipated due to the pressure drop in the lower 7-10 stages of the MOUDI sampler while such a loss was avoided in the $\mathrm{PM}_{2.5}$ sampler as the nylon filter substrates effectively retain ammonium nitrate. A strong temperature dependence was also observed in the correlation of nitrate between the two sets of measurements. The correlation in winter $\left(R^{2}=0.96\right.$, slope $=1.17)$ was much better than that in summer $\left(R^{2}=\right.$ 0.13 , slope $=-2.58$ ), reflecting the increased dissociation of ammonium nitrate, and thereby more volatile loss of nitrate at higher ambient temperatures.

In summary, the comparisons indicate that the MOUDI measurements for the less volatile ionic species are reliable while nitrate measurements by MOUDI were subjected to sampling artifacts due to volatile loss. The undersampling of nitrate was more significant for summer samples than for winter samples.

\subsection{Size distribution characteristics}

Ambient aerosol size distribution is characterized by multiple modes - i.e., nucleation mode, condensation mode, droplet mode and coarse mode - each of which corresponds to distinct aerosol sources and formation pathways. For example, particles in the condensation mode are usually 


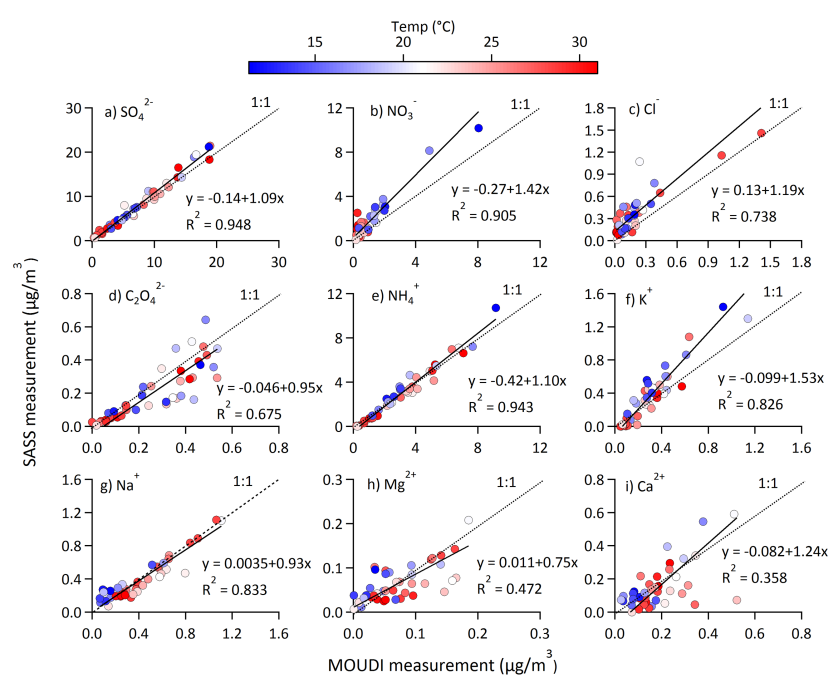

Figure 1. Comparison between MOUDI measurements $(<3.2 \mu \mathrm{m})$ and $\mathrm{PM}_{2.5}$ measurements with the SASS sampler. Orthogonal distance regression is applied to examine the comparison. Data points are color-coded by ambient temperatures on the individual sampling days. A segregation of data points by temperature was observed for nitrate; see text for details.

relatively fresh aerosols while the droplet-mode particles may have gone through in-cloud processing and are more likely linked to regional/super-regional transport (Meng and Seinfeld, 1994).

The continuous size distributions were inverted from measurements for the limited number of size bins by adapting the Twomey algorithm on the known response function of the cascade impactor (Twomey, 1975; Winklmayr et al., 1990). Trimodal log-normal distributions were used to fit the measured data in this work on the assumption that the ambient particle population is a superposition of three lognormal modes (i.e., condensation, droplet, and coarse modes) (Dzubay and Hasan, 1990; Dong et al., 2004). The modal concentrations and MMADs are listed in Table 1. The fitted size distributions fall into two groups: a group with a dominant condensation mode (Fig. 2a), and a group with a prominent coarse mode (Fig. 2b). More details are discussed in the ensuing sections.

\subsubsection{Size distributions of $\mathrm{NH}_{4}^{+}, \mathrm{SO}_{4}^{2-}, \mathrm{C}_{2} \mathrm{O}_{4}^{2-}$ and $\mathrm{K}^{+}$}

The first group of ionic species, including $\mathrm{NH}_{4}^{+}, \mathrm{SO}_{4}^{2-}$, $\mathrm{C}_{2} \mathrm{O}_{4}^{2-}$ and $\mathrm{K}^{+}$, share the common characteristic of a dominant droplet mode (Fig. 2a). The size distribution patterns for $\mathrm{SO}_{4}^{2-}$ and $\mathrm{NH}_{4}^{+}$are very similar, with MMAD of $\sim 0.2 \mu \mathrm{m}$ for the condensation mode, $\sim 0.8 \mu \mathrm{m}$ for the droplet mode, and $4.0-5.0 \mu \mathrm{m}$ for the coarse mode. The fractions of $\mathrm{SO}_{4}^{2-}$ in these three modes were $3.0-5.9,75-81$ and $14-21 \%$, respectively. The percentages of $\mathrm{NH}_{4}^{+}$were 3.4-4.7, 81-89 and $4.2-16 \%$, respectively. The molar ratio of $2 \times\left[\mathrm{SO}_{4}^{2-}\right]$ and
$\left[\mathrm{NH}_{4}^{+}\right]$in particles of $<3.2 \mu \mathrm{m}\left(\mathrm{PM}_{3.2}\right)$ was 1.04 , indicating that fine sulfate mainly existed in the form of ammonium sulfate.

Air masses influencing HK vary with the shift of synopticscale meteorology in the PRD from season to season. In this study, the season breakdown adopts the definition by Louie et al. (2005); that is, spring is from March to May, summer is from June to August, fall is from September to November, and winter is from December to February. No significant seasonality in size distribution pattern was observed for $\mathrm{SO}_{4}^{2-}$ and $\mathrm{NH}_{4}^{+}$. Sulfate and ammonium were most abundant in the spring, mainly due to the increase of mass concentration in the droplet mode.

$\mathrm{C}_{2} \mathrm{O}_{4}^{2-}$ shows a similar size distribution pattern to that of sulfate. The MMADs of the condensation, droplet, and coarse modes were $0.1-0.2,0.7-0.9$ and $4.0-5.0 \mu \mathrm{m}$, respectively, and the mass percentages were $0-8.1,73-82$ and 18 $21 \%$, respectively. Several sources are known to contribute to the atmospheric presence of oxalate, including secondary formation through the oxidation of oxygenated VOCs (e.g., glyoxal) (e.g, Warneck, 2003; Carlton et al., 2007); biomass burning (Allen et al., 2004; Kundu et al., 2010), and meat charbroiling (Rogge et al., 1991). Yu et al. (2005) observed good correlations between ambient oxalate and sulfate measurements across a wide geographical span in eastern Asia and argued that a common dominant formation pathway, likely in-cloud processing, could explain the close tracking of the two chemically distinct species. For the samples taken in this work, the correlation between the two species in the $0.56-1.0 \mu \mathrm{m}$ size bin was good $\left(R^{2}=0.69\right)$, in agreement with the suggestion of the common in-cloud processing formation process.

It is noted that the MMAD and standard deviation $\left(\sigma_{g}\right)$ of the droplet-mode oxalate in summer were noticeably larger than those of sulfate while the MMAD and $\sigma_{g}$ values of the two species were similar in the other seasons. This prompted us to examine the mass concentration ratios of both oxalate and sulfate between the two size bins of 1.0-1.8 and 0.56$1.0 \mu \mathrm{m}$ (Fig. 3). It is clear that the $\mathrm{SO}_{4}^{2-}$ ratio between the two size bins was lower than the $\mathrm{C}_{2} \mathrm{O}_{4}^{2-}$ ratio on sampling days with temperatures higher than $22^{\circ} \mathrm{C}$ (mostly in summer) while the ratios for the two species were comparable in the other seasons. Oxalic acid was reported to partition between the gas phase and particles under ambient conditions (Limbeck et al., 2001). The enhanced presence of oxalate in the size range of $1.0-1.8 \mu \mathrm{m}$ could be explained by evaporation of oxalic acid from the smaller-size particles followed by condensation onto larger particles due to their higher alkalinity. This evaporation-and-recondensation process was proposed by Yao et al. (2002, 2003), Mochida et al. (2003) and Sullivan and Prather (2007). Another possible explanation for the increased supermicron oxalate is more active photochemical oxidation in the gas phase in summer followed by 
Table 1. Mass mean aerodynamic diameters (MMAD, $\mu \mathrm{m})$, standard deviation $\left(\sigma_{g}\right)$ and modal concentrations of ionic species $\left(C_{\mathrm{m}}, \mu \mathrm{g} \mathrm{m}^{-3}\right)$ in spring $(N=8, N$ represents number of samples), summer $(N=11)$, fall $(N=13)$ and winter $(N=11)$.

\begin{tabular}{|c|c|c|c|c|c|c|c|c|c|}
\hline \multirow[t]{2}{*}{ (a) } & \multicolumn{3}{|c|}{ Condensation mode } & \multicolumn{3}{|c|}{ Droplet mode } & \multicolumn{3}{|c|}{ Coarse mode } \\
\hline & $\begin{array}{r}C_{\mathrm{m}} \\
\left(\mu \mathrm{g} \mathrm{m}^{-3}\right)\end{array}$ & $\begin{array}{r}\text { MMAD } \\
(\mu \mathrm{m})\end{array}$ & $\sigma_{g}$ & $\begin{array}{r}C_{\mathrm{m}} \\
\left(\mu \mathrm{g} \mathrm{m}^{-3}\right)\end{array}$ & $\begin{array}{r}\text { MMAD } \\
(\mu \mathrm{m})\end{array}$ & $\sigma_{g}$ & $\begin{array}{r}C_{\mathrm{m}} \\
\left(\mu \mathrm{g} \mathrm{m}^{-3}\right)\end{array}$ & $\begin{array}{r}\text { MMAD } \\
(\mu \mathrm{m})\end{array}$ & $\sigma_{g}$ \\
\hline \multicolumn{10}{|l|}{$\mathrm{SO}_{4}^{2-}$} \\
\hline *Spring & 0.59 & 0.24 & 1.31 & 9.51 & 0.84 & 1.51 & 2.64 & 5.07 & 2.07 \\
\hline Summer & 0.32 & 0.25 & 1.34 & 5.30 & 0.83 & 1.54 & 0.91 & 5.13 & 2.06 \\
\hline Fall & 0.56 & 0.28 & 1.30 & 7.30 & 0.80 & 1.38 & 1.63 & 4.38 & 2.31 \\
\hline Winter & 0.26 & 0.26 & 1.25 & 6.78 & 0.84 & 1.50 & 1.62 & 5.03 & 2.16 \\
\hline \multicolumn{10}{|l|}{$\mathrm{NH}_{4}^{+}$} \\
\hline Spring & 0.26 & 0.24 & 1.38 & 3.79 & 0.82 & 1.49 & 0.63 & 4.92 & 2.14 \\
\hline Summer & 0.14 & 0.26 & 1.35 & 1.94 & 0.82 & 1.53 & 0.09 & 5.02 & 2.35 \\
\hline Fall & 0.23 & 0.30 & 1.30 & 2.64 & 0.78 & 1.36 & 0.20 & 4.25 & 2.51 \\
\hline Winter & 0.12 & 0.26 & 1.26 & 2.86 & 0.84 & 1.50 & 0.56 & 5.06 & 2.17 \\
\hline \multicolumn{10}{|l|}{$\mathrm{K}^{+}$} \\
\hline Spring & 0.03 & 0.22 & 2.18 & 0.23 & 0.81 & 1.49 & 0.10 & 5.09 & 2.05 \\
\hline Summer & 0.00 & 0.16 & 2.17 & 0.12 & 0.78 & 1.63 & 0.07 & 5.73 & 1.77 \\
\hline Fall & 0.01 & 0.28 & 1.25 & 0.22 & 0.81 & 1.46 & 0.08 & 5.89 & 1.81 \\
\hline Winter & 0.02 & 0.28 & 1.27 & 0.34 & 0.79 & 1.49 & 0.09 & 4.70 & 2.16 \\
\hline \multicolumn{10}{|l|}{$\mathrm{C}_{2} \mathrm{O}_{4}^{2-}$} \\
\hline Spring & 0.02 & 0.22 & 1.35 & 0.30 & 0.80 & 1.66 & 0.08 & 4.58 & 1.81 \\
\hline Summer & 0.00 & 0.12 & 1.51 & 0.18 & 0.92 & 2.02 & 0.04 & 5.25 & 1.64 \\
\hline Fall & 0.03 & 0.11 & 2.59 & 0.27 & 0.84 & 1.66 & 0.07 & 4.83 & 1.81 \\
\hline Winter & 0.01 & 0.29 & 1.28 & 0.21 & 0.77 & 1.49 & 0.06 & 4.58 & 2.12 \\
\hline \multirow[t]{2}{*}{ (b) } & \multicolumn{3}{|c|}{ Droplet mode } & \multicolumn{3}{|c|}{ Coarse-mode I } & \multicolumn{3}{|c|}{ Coarse-mode II } \\
\hline & $\begin{array}{r}C_{\mathrm{m}} \\
\left(\mu \mathrm{g} \mathrm{m}^{-3}\right)\end{array}$ & $\begin{array}{r}\text { MMAD } \\
(\mu \mathrm{m})\end{array}$ & $\sigma_{g}$ & $\begin{array}{r}C_{\mathrm{m}} \\
\left(\mu \mathrm{g} \mathrm{m}^{-3}\right)\end{array}$ & $\begin{array}{r}\text { MMAD } \\
(\mu \mathrm{m})\end{array}$ & $\sigma_{g}$ & $\begin{array}{r}C_{\mathrm{m}} \\
\left(\mu \mathrm{g} \mathrm{m}^{-3}\right)\end{array}$ & $\begin{array}{r}\text { MMAD } \\
(\mu \mathrm{m})\end{array}$ & $\sigma_{g}$ \\
\hline \multicolumn{10}{|l|}{$\mathrm{NO}_{3}^{-}$} \\
\hline Spring & 0.74 & 0.91 & 1.55 & 2.28 & 4.18 & 1.42 & 2.50 & 7.38 & 1.24 \\
\hline Summer & 0.09 & 0.77 & 2.18 & 0.44 & 3.40 & 1.49 & 0.87 & 7.19 & 1.42 \\
\hline Fall & 0.14 & 1.03 & 2.61 & 1.47 & 4.03 & 1.45 & 1.54 & 7.33 & 1.25 \\
\hline Winter & 1.43 & 0.88 & 1.44 & 0.84 & 2.96 & 1.53 & 1.56 & 6.83 & 1.44 \\
\hline \multicolumn{10}{|l|}{$\mathrm{Na}^{+}$} \\
\hline Spring & 0.43 & 0.90 & 2.06 & 1.00 & 4.07 & 1.43 & 1.36 & 7.49 & 1.28 \\
\hline Summer & 0.14 & 1.21 & 1.61 & 0.66 & 3.62 & 1.51 & 0.95 & 7.37 & 1.35 \\
\hline Fall & 0.16 & 1.17 & 1.61 & 0.72 & 3.48 & 1.51 & 1.45 & 7.64 & 1.32 \\
\hline Winter & 0.11 & 1.10 & 1.73 & 0.22 & 3.40 & 1.38 & 0.85 & 7.67 & 1.39 \\
\hline \multicolumn{10}{|l|}{$\mathrm{Mg}^{2+}$} \\
\hline Spring & 0.01 & 1.24 & 1.45 & 0.11 & 3.32 & 1.50 & 0.22 & 6.92 & 1.39 \\
\hline Summer & 0.01 & 1.15 & 1.54 & 0.06 & 3.09 & 1.51 & 0.15 & 7.06 & 1.47 \\
\hline Fall & 0.01 & 1.28 & 1.54 & 0.08 & 3.25 & 1.53 & 0.18 & 7.62 & 1.33 \\
\hline Winter & 0.01 & 1.11 & 1.57 & 0.03 & 3.15 & 1.51 & 0.11 & 7.62 & 1.45 \\
\hline \multicolumn{10}{|l|}{$\mathrm{Ca}^{2+}$} \\
\hline Spring & 0.11 & 1.04 & 2.12 & 0.27 & 3.44 & 1.45 & 0.50 & 6.99 & 1.40 \\
\hline Summer & 0.01 & 1.14 & 1.50 & 0.09 & 3.11 & 1.45 & 0.33 & 7.68 & 1.47 \\
\hline Fall & 0.04 & 0.85 & 1.35 & 0.16 & 3.96 & 1.51 & 0.24 & 7.59 & 1.28 \\
\hline Winter & 0.02 & 1.16 & 1.81 & 0.10 & 3.34 & 1.43 & 0.33 & 7.53 & 1.44 \\
\hline \multicolumn{10}{|l|}{$\mathrm{Cl}^{-}$} \\
\hline Spring & 0.09 & 1.35 & 1.87 & 0.26 & 3.84 & 1.26 & 1.67 & 7.76 & 1.28 \\
\hline Summer & 0.04 & 1.48 & 1.76 & 0.81 & 3.89 & 1.46 & 1.34 & 7.49 & 1.32 \\
\hline Fall & 0.04 & 1.59 & 1.52 & 0.24 & 3.56 & 1.25 & 1.96 & 7.89 & 1.33 \\
\hline Winter & 0.05 & 1.27 & 1.79 & 0.10 & 3.37 & 1.25 & 1.01 & 8.09 & 1.39 \\
\hline
\end{tabular}

* Spring is defined as the period from March to May, summer is from June to August, fall is from September to November, and winter is from December to February. 

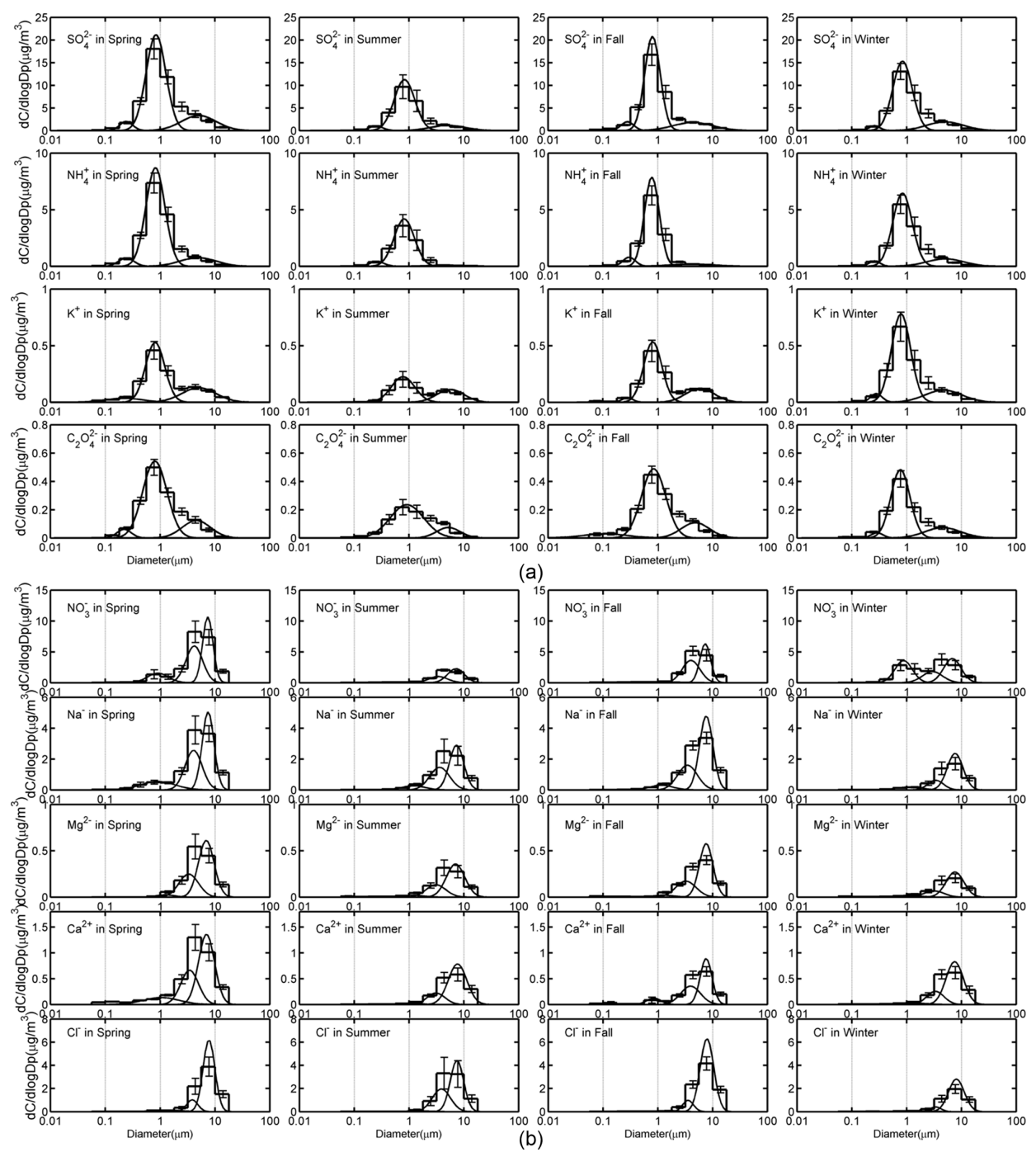

Figure 2. Continuous log-normal size distributions of (a) species associated with in-cloud processing $\left(\mathrm{SO}_{4}^{2-}, \mathrm{NH}_{4}^{+}, \mathrm{K}^{+}, \mathrm{C}_{2} \mathrm{O}_{4}^{2-}\right)$ and (b) species associated with crustal and sea salt particles $\left(\mathrm{NO}_{3}^{-}, \mathrm{Na}^{+}, \mathrm{Mg}^{2+}, \mathrm{Ca}^{2+}, \mathrm{Cl}^{-}\right)$in the four seasons. The size distributions are inverted from measured MOUDI data, which are shown in histograms.

preferential condensation onto the more-alkaline larger particles (Rinaldi et al., 2011; van Pinxteren et al., 2014).

The dominant presence of $\mathrm{K}^{+}$in the droplet mode could be explained by the fact that the $\mathrm{K}^{+}$-containing particles can be easily cloud-activated. The good correlation $\left(R^{2}=0.64\right)$ between $\mathrm{K}^{+}$and $\mathrm{SO}_{4}^{2-}$ in the size bin of $0.56-1.0 \mu \mathrm{m}$ supports the suggestion of in-cloud processes. The condensation mode of $\mathrm{K}^{+}$, accounting for a small fraction (1.1-8.6\%), may be mostly from fresh biomass burning emissions. $\mathrm{K}^{+}$in the coarse mode (20-37\%) might originate from sea salt, soil or the coagulation of small biomass-burning particles onto coarse particles.

\subsubsection{Size distributions of nitrate, sea salt species, and crustal species}

The second group of ionic species, including $\mathrm{NO}_{3}^{-}, \mathrm{Na}^{+}$, $\mathrm{Cl}^{-}, \mathrm{Ca}^{2+}$, and $\mathrm{Mg}^{2+}$, share the common size distribution characteristic of a prominent coarse mode (Fig. 2b). Both bimodal (one fine mode and one coarse mode) and trimodal (i.e., one fine mode and two coarse modes) fitting of the measurement data were carried out. In the case of bimodal lognormal fitting, the Twomey algorithm would result in skewed log-normal distribution curves (Fig. S3 in the Supplement). On the other hand, trimodal data fitting is able to capture the measured size distributions with three log-normally distrusted particle populations (Fig. 2b). The inverted size distributions for this group of species are therefore represented with one fine and two coarse modes. The underlying physical 


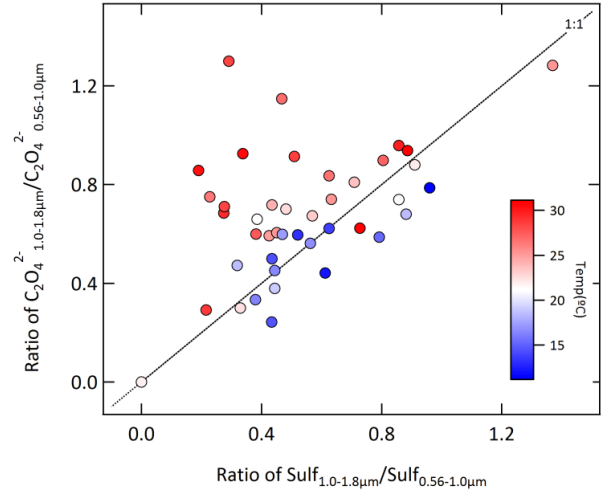

Figure 3. Comparison of mass concentration ratios of oxalate and sulfate between the two size bins $1.0-1.8$ and $0.56-1.0 \mu \mathrm{m}$. The data points are color-coded according to ambient temperature during their collection.

basis for the presence of two coarse modes will be discussed in detail in a later section.

The droplet-mode MMAD values for all five species ranged from 0.8 to $1.5 \mu \mathrm{m}$. The MMAD of the smaller coarse mode (I) ranged from 3.0 to $4.2 \mu \mathrm{m}$ and the larger coarse mode (II) ranged from 6.8 to $8.1 \mu \mathrm{m}$ for sea salt species $\left(\mathrm{Na}^{+}, \mathrm{Mg}^{2+}\right.$, and $\left.\mathrm{Cl}^{-}\right)$. Andreas (1998) summarized that sea spray droplets fall into three types and their respective size ranges are film droplets $(0.5-5 \mu \mathrm{m})$, jet droplets $(3-50 \mu \mathrm{m})$ and spume droplets $(>20 \mu \mathrm{m})$. Film droplets are ejected due to the rupturing of the film-thin top of oceanic bubbles on the surface of the sea; jet bubbles are formed from the bottom of surface bubbles after their burst; and spume droplets are produced when the wind tears seawater right off the wave crests. The two coarse modes retrieved for the sea salt species likely correspond to film droplets and jet droplets. Sea salt particles of spume droplets are not expected to be captured by MOUDI sampling as this sampler only collects particles of up to $18 \mu \mathrm{m}$. This sea salt particle formation theory also explained the small amount of sea salt in the droplet mode $(<2.5 \mu \mathrm{m})$.

The mass concentration of sea salt aerosol was averagely lower in the summer and winter than in the spring and fall (Table 1). Wai and Tanner (2004) suggested that sea salt particle concentration is closely dependent on wind speed and seawater salinity. The wind speed at the site was lower in the summer while the speed in the winter was similar to those in the spring and fall (Fig. S2 in the Supplement). Thus, it is unlikely that the wind speed was a dominant factor affecting the concentration of sea salt aerosols at the sampling site. Thiyagarajan et al. (2002) reported that salinity in eastern HK was the highest (34\%o) in spring, the next highest (32\%o) in fall and lower $(30 \%)$ in the summer and winter. The lower salinity around HK waters in summer and winter is due to the input of fresh water plumes from the Pearl River and the Yangtze River, respectively (Guan and Fang, 2006; Gan et al., 2009). It is plausible that the higher salinity of seawater in spring and fall explained the higher abundance of the sea salt ionic species in the atmosphere. Current regional air quality models only consider the influence of wind speed and RH on the sea salt concentration in the coastal surf zone (Kelly et al., 2010). Our results suggest that the oceanic salinity may need to be considered in the parameterization of sea salt emissions in air quality models.

Soluble $\mathrm{Ca}^{2+}$ is the product of soil components (i.e., calcium carbonate) reacting with acidic gases (e.g., $\mathrm{HNO}_{3}$ ) or co-existing acidic aerosol components (e.g., $\mathrm{H}_{2} \mathrm{SO}_{4}, \mathrm{HSO}_{4}^{-}$). The larger coarse mode (MMAD: 7.0-7.7 $\mu \mathrm{m}$ ) accounted for a dominant fraction (55-77\%), the smaller coarse mode (MMAD: $3.1-4.0 \mu \mathrm{m}$ ) accounted for $21-37 \%$, and a minor fraction $(2-12 \%)$ was in the fine mode (Table 1). The smaller coarse-mode $\mathrm{Ca}^{2+}$ is likely associated with longrange-transported dust particles while the larger coarse mode is mainly associated with locally produced soil particles. Such a differentiation of two coarse-mode dust particles with respect to different source origins was previously suggested by Husar (2004) and VanCuren et al. (2005). $\mathrm{Ca}^{2+}$ in the fine and in the smaller coarse modes was found to correlate strongly with $\mathrm{Si}$ in the collocated $\mathrm{PM}_{2.5}$ samples ( $R^{2}=0.54$ and 0.80 , respectively) (Fig. 4 ) while $\mathrm{Ca}^{2+}$ in the large coarse mode had a much weaker correlation with $\mathrm{Si}$ in $\mathrm{PM}_{2.5}\left(R^{2}=0.24\right)$. This result further supports the hypothesis that the smaller coarse-mode $\mathrm{Ca}^{2+}$ might be associated with long-range-transported dust particles. The mass concentration of $\mathrm{Ca}^{2+}$ in spring was $\sim 1.4-2.2$ times higher than those in other seasons, indicating the increased influence of dust transported from the North China Plain on HK in this season (Lee et al., 2010).

Nitrate is closely associated with sea salt and dust particles as a result of its formation process through the reactions of acidic $\mathrm{HNO}_{3}$ gas with alkaline components (e.g., Harrison and Pio, 1983). Fitting the measured nitrate size distributions with three log-normal distributions produces a droplet mode of MMAD in the range of $0.8-1.0 \mu \mathrm{m}(2-13 \%)$, coarsemode I of MMAD in the range of 3.0-4.2 $\mu \mathrm{m}(22-47 \%)$, and coarse-mode II of MMAD in the range of $6.8-7.4 \mu \mathrm{m}$ (41-62\%). Unlike other ionic species, the relative abundance of nitrate in different size modes is highly variable between the seasons. The average percentage of aerosol nitrate in the fine mode $(<1.8 \mu \mathrm{m})$, denoted as $P_{\mathrm{n} \_ \text {fine }}$ hereafter, was significantly higher in the winter samples $(37 \%)$ than those in the spring $(13 \%)$, summer and fall $(\leq 6 \%)$.

\subsubsection{Factors affecting fine-mode nitrate}

Fine-mode nitrate is mainly in the form of $\mathrm{NH}_{4} \mathrm{NO}_{3}$ while the coarse-mode nitrate is the product of a heterogeneous reaction between gaseous $\mathrm{NO}_{2}$ or $\mathrm{HNO}_{3}$ and alkaline species such as $\mathrm{Ca}^{2+}$ and $\mathrm{Na}^{+}$(Pakkanen et al., 1996; Yoshizumi and Hoshi, 1985). $\mathrm{NH}_{4} \mathrm{NO}_{3}$ is a thermally unstable species and its abundance in aerosols is governed by the following 


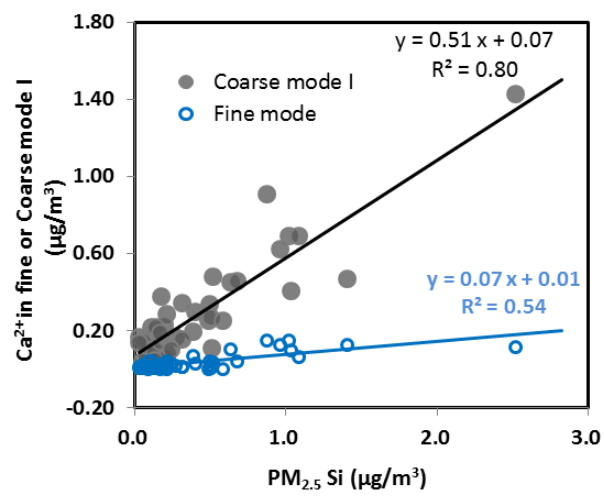

Figure 4. Correlations of $\mathrm{Ca}^{2+}$ in fine-mode and coarse-mode I with $\mathrm{Si}$ in collocated $\mathrm{PM}_{2.5}$ samples.

thermodynamic equilibrium:

$\mathrm{NH}_{4} \mathrm{NO}_{3}(\mathrm{~s}, \mathrm{aq}) \Leftrightarrow \mathrm{HNO}_{3}(\mathrm{~g})+\mathrm{NH}_{3}(\mathrm{~g})$.

The amount of aerosol $\mathrm{NH}_{4} \mathrm{NO}_{3}$ is dependent on $\mathrm{RH}$, temperature $(T)$, and concentrations of gas-phase nitric acid and ammonia (Mozurkewich, 1993). Under the RH conditions at the sampling site (normally larger than $80 \%$ during the sampling period) (Fig. S2 in the Supplement), calculations using the thermodynamic equilibrium model (i.e., ISORROPIA) show that the nitrate particles were in the aqueous status.

The dissociation constant $\left(K_{e}\right)$ is inherently dependent on RH and $T$ (Mozurkewich, 1993). In addition, the ionic strength of the aerosol aqueous phase also influences the gasparticle partitioning of $\mathrm{NH}_{4} \mathrm{NO}_{3}$. For instance, coexistence of $\mathrm{SO}_{4}^{2-}$ in particles reduces $K_{e}$ in the $\mathrm{NH}_{4}^{+} / \mathrm{NO}_{3}^{-} / \mathrm{SO}_{4}^{2-}$ system and helps to retain nitrate in the aerosol phase (Stelson and Seinfeld, 1982; Seinfeld and Pandis, 2006). For this reason, a modified dissociation constant $K_{e}^{\prime}$ is introduced to take into consideration of the ionic strength effect. $K_{e}^{\prime}$ is defined to be the product of $K_{e}$ and $Y$, where $Y$ is $\left[\mathrm{NH}_{4} \mathrm{NO}_{3}\right] /\left(\left[\mathrm{NH}_{4} \mathrm{NO}_{3}\right]+3\left[\left(\mathrm{NH}_{4}\right)_{2} \mathrm{SO}_{4}\right]\right)$. Our calculations showed that $K_{e}^{\prime}$ varied from 0.06 to $5.1 \mathrm{ppb}^{2}$ (parts per billion squared) for individual samples and was less than $1.5 \mathrm{ppb}^{2}$ for most of the samples collected in spring and winter (Fig. S4 in the Supplement). The plot of $K_{e}^{\prime}$ vs. $P_{\mathrm{n}_{-} \text {fine }}$ (Fig. 5a) shows a clear inverse relationship between the two variables, and $P_{\mathrm{n}_{-} \text {fine }}$ is significant $(>10 \%)$ only when $K_{e}^{\prime}$ falls below $1.0 \mathrm{ppb}^{2}$.

Due to the tendency of gaseous $\mathrm{HNO}_{3} / \mathrm{N}_{2} \mathrm{O}_{5}$ reacting with alkaline sea salt and soil particles (Reactions R2-R4) (Yao and Zhang, 2012), the alkaline species compete for gaseous $\mathrm{HNO}_{3}$ and thus the abundance of the alkaline species is expected to affect the amount of $\mathrm{NH}_{4} \mathrm{NO}_{3}$ partitioning onto the fine particles:

$\mathrm{NaCl}(\mathrm{s})+\mathrm{HNO}_{3}(\mathrm{~g}) \rightarrow \mathrm{NaNO}_{3}(\mathrm{~s})+\mathrm{HCl}(\mathrm{g}) \uparrow$,
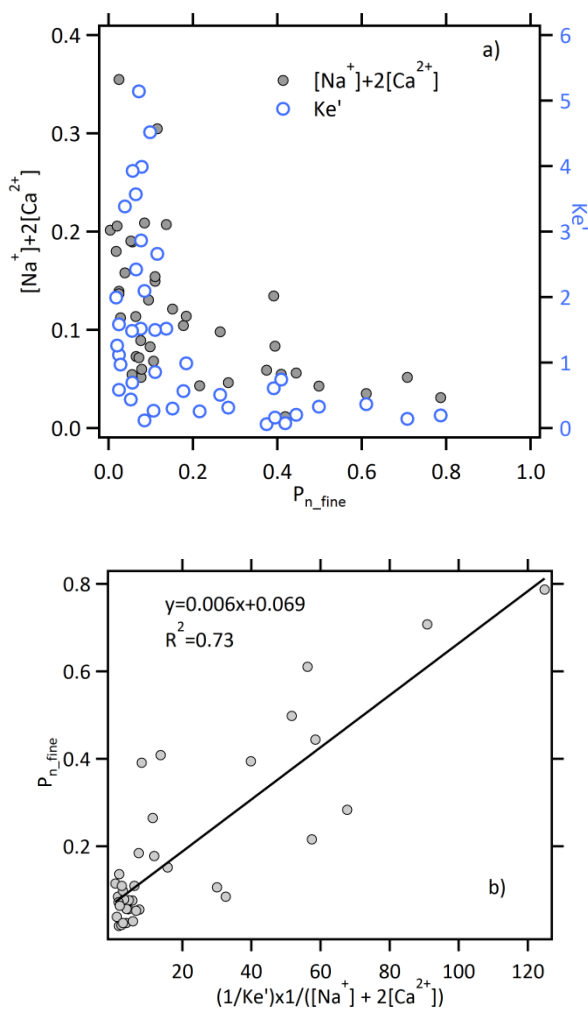

Figure 5. (a) Relationships of aerosol nitrate fraction in the fine mode $\left(P_{\mathrm{n} \text { fine }}\right)(<1.8 \mu \mathrm{m})$ with a modified $\mathrm{NH}_{4} \mathrm{NO}_{3}$ dissociation equilibrium constant $\left(K_{e}^{\prime}\right)$ and equivalent amounts of $\left[\mathrm{Na}^{+}\right]+2\left[\mathrm{Ca}^{2+}\right]$ in the size range $>3.2 \mu \mathrm{m}$; (b) empirical relationship between $P_{\mathrm{n} \_ \text {fine }}$ and $\left(1 / K_{e}^{\prime}\right) \times 1 /\left(\left[\mathrm{Na}^{+}\right]+2\left[\mathrm{Ca}^{2+}\right]\right)$.

$$
\begin{aligned}
& \mathrm{NaCl}(\mathrm{s})+\mathrm{N}_{2} \mathrm{O}_{5}(\mathrm{~g}) \rightarrow \mathrm{NaNO}_{3}(\mathrm{~s})+\mathrm{ClNO}_{2}(\mathrm{~g}) \uparrow, \\
& \mathrm{CaCO}_{3}(\mathrm{~s})+2 \mathrm{HNO}_{3}(\mathrm{~g}) \\
& \quad \rightarrow \mathrm{Ca}\left(\mathrm{NO}_{3}\right)_{2}(\mathrm{~s})+\mathrm{H}_{2} \mathrm{O}+\mathrm{CO}_{2}(\mathrm{~g}) \uparrow .
\end{aligned}
$$

The sum of the two major ions $\left(\mathrm{Na}^{+}\right.$and $\mathrm{Ca}^{2+}$ ) (in equivalent concentrations) is indicative of the abundance of alkaline species on sea salt and soil particles. It is plotted against $P_{\mathrm{n}_{-} \text {fine }}$ in Fig. 5a and a clear inverse relationship is observed. The coarse-mode equivalent concentration of

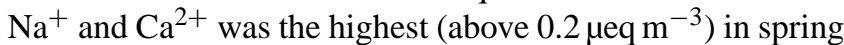
(Fig. S4 in the Supplement), which explains the less significant presence of fine-mode nitrate in samples collected in spring than those in winter. The following empirical relationship is found between $P_{\mathrm{n}_{-} \text {fine }}$ and the product of $\left(1 / K_{e}^{\prime}\right)$ and $\left(1 /\left[\mathrm{Na}^{+}\right]+2\left[\mathrm{Ca}^{2+}\right]\right)(\mathrm{Fig} .5 \mathrm{~b})$ :

$$
\begin{aligned}
P_{\mathrm{n}_{-} \text {fine }} & =0.006 \times\left(\frac{1}{K_{e}^{\prime}}\right) \\
& \times\left(\frac{1}{\left[\mathrm{Na}^{+}\right]+2\left[\mathrm{Ca}^{2+}\right]}\right)+0.069, R^{2}=0.73 .
\end{aligned}
$$


Due to the limited sample size and the negative sampling artifact in nitrate by MOUDI, there is a significant degree of scattering in the plot. As shown by Fig. 5b, the fitting equation is largely driven by data points when $P_{\mathrm{n}_{-} \text {fine }}$ is significant (> 10\%). As such, whether this equation is applicable to scenarios of small $P_{\mathrm{n}_{-} \text {fine }}$ can only be evaluated after more and better quality measurements are made in this regime. Nevertheless, this result indicates that, in coastal environments, sea salt plays an active role in modulating the amount of nitrate residing in the fine-mode particles.

\subsubsection{Relationship of coarse-mode nitrate formation and chloride depletion}

Coarse-mode nitrate formation and chloride depletion on sea salt particles are closely linked through Reaction (R2). The percentages of the chloride depleted $\left(\mathrm{Cl}_{\text {depletion }}^{-} \%\right)$ for size bins larger than $3.2 \mu \mathrm{m}$ were calculated and summarized in Table 2. Generally, the extent of $\mathrm{Cl}^{-}$depletion is progressively higher on relatively smaller particles, which is an expected result of more abundant acidic species on the smaller particles. The equivalent ratios of $\left[\mathrm{Cl}^{-}+\mathrm{NO}_{3}^{-}\right] /\left[\mathrm{Na}^{+}\right]$on coarse particles ranged from 1.20 to 1.88 , which were close to the $\left[\mathrm{Cl}^{-}\right] /\left[\mathrm{Na}^{+}\right]$ratio in seawater (1.174). It is suggested by Yao and Zhang (2012) that this similarity indicates that the overall chloride depletion could be largely explained by the coarse-mode nitrate formation. MARGA data also showed that the measured $\mathrm{HNO}_{3}(\mathrm{~g})$ and $\mathrm{HCl}(\mathrm{g})$ were moderately correlated in the regime of low $P_{\mathrm{n}_{-} \text {fine }}$ (percentage of fine-mode nitrate $<30 \%$ ) (Fig. S5 in the Supplement), supporting Reaction (R2) as a significant pathway for $\mathrm{Cl}^{-}$depletion.

\subsubsection{Comparison of size distributions of secondary ionic species with previous studies}

Table $\mathrm{S} 1$ in the Supplement lists the measurements of MMAD of $\mathrm{SO}_{4}^{2-}, \mathrm{NO}_{3}^{-}, \mathrm{NH}_{4}^{+}$and $\mathrm{C}_{2} \mathrm{O}_{4}^{2-}$ at the HKUST site in the past decades. The MMAD of the condensation mode slightly increased from $\sim 0.2 \mu \mathrm{m}$ in 1996 (Zhuang et al., 1999b) to $\sim 0.3 \mu \mathrm{m}$ in 2008 (Yu et al., 2010) and in this study. The MMAD of the droplet mode for sulfate increased from $\sim 0.6 \mu \mathrm{m}$ in 1996 to $0.8-0.9 \mu \mathrm{m}$ in 2008 and in 20112012 (this study). It is difficult to discern whether this observation of shift of the droplet mode to a large size was incidental (due to the limited measurements and the low temporal resolution in the MOUDI measurements) or reflected increased contributions of sulfate via regional transport in the recent measurement periods. $\mathrm{SO}_{4}^{2-}$ was neutralized by gaseous $\mathrm{NH}_{3}$ in the atmosphere and $\mathrm{NH}_{4}^{+}$thus has the similar variation of size distribution as $\mathrm{SO}_{4}^{2-}$ (Zhuang et al., 1999b; Louie et al., 2005).

In the winter of 1996-1997, coarse-mode nitrate was dominant, with a MMAD of $3.95 \mu \mathrm{m}$ while in the winter of 2008 and in 2011-2012, nitrate exhibited bimodal distributions.
The fine-mode nitrate concentration was $0.58,1.01$ and

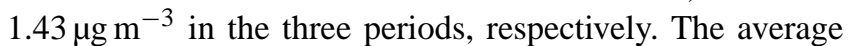
concentration of the gaseous precursor $\left(\mathrm{NO}_{\mathrm{x}}\right)$ was $\sim 7.7 \mathrm{ppb}$ in the winter of 1999 and 2000, $13.8 \mathrm{ppb}$ in the winter of 2008 and $\sim 10.3 \mathrm{ppb}$ in this study, respectively. The increasing concentration level of $\mathrm{NO}_{\mathrm{x}}$ would lead to higher local production of $\mathrm{HNO}_{3}$. It is likely that alkaline species were insufficient to neutralize the increased $\mathrm{HNO}_{3}$ or $\mathrm{NO}_{3}^{-}$and thus a larger proportion of $\mathrm{HNO}_{3}$ partitions to the fine particles.

No oxalate concentration was reported in the data set of 1996-1997. MMADs in the condensation mode, droplet mode and coarse mode of this species were comparable in 2008 and in 2011-2012.

\subsection{PMF analysis of size-segregated sulfate with selected gaseous pollutants}

Multivariate receptor modeling has been widely used to identify the underlying emission sources and formation processes and to estimate source contributions to measured ambient particulate concentration. Several studies have succeeded in applying factor analytic algorithms (PMF and multilinear engine (ME-2)) to size distribution measurements to retrieve source contribution on the assumption of a unique size distribution for each contributing source and linearity between particle number and mass concentration over time at a fixed site (Kim et al., 2004; Zhou et al., 2004, 2005). In the following analysis, the PMF approach was adopted to estimate the relative contributions of local formation and regional/superregional transport to the observed ambient sulfate.

\subsubsection{PMF analysis of size-segregated sulfate}

The 43 sets of size-segregated sulfate concentrations were combined with the gaseous pollutant measurements $(\mathrm{CO}$, $\mathrm{SO}_{2}$ and $\mathrm{O}_{\mathrm{x}}$ ) for PMF analysis using EPA PMF3.0. $\mathrm{SO}_{2}$ is the gaseous precursor of particulate sulfate. $\mathrm{O}_{\mathrm{x}}$ (the sum of $\mathrm{NO}_{2}$ and $\mathrm{O}_{3}$ ) is usually used to evaluate the oxidation capability of ambient atmosphere. $\mathrm{CO}$ is generally considered as an anthropogenic combustion tracer. Diurnal variation of $\mathrm{CO}$ at our measurement site was almost flat and no rush hour peak was observed (Fig. S6 in the Supplement). This was clearly different from the diurnal patterns of elemental carbon and $\mathrm{NO}_{\mathrm{x}}$ as observed at a roadside location in Hong Kong showing concentration peaks during local rush hours in the morning and in the early evening (Huang et al., 2014b). Hence, the diurnal pattern of $\mathrm{CO}$ rules out vehicular emissions from nearby roads in the vicinity of a few kilometers as a major contributor to at HKUST. This is reasonable in view of that the roads near HKUST do not carry heavy traffic as the university is located in a low population density residential district in Hong Kong. To the best of our knowledge, there are no other obvious combustion sources near the sampling location. When seasonal variations were examined, 
Table 2. The percentage of $\mathrm{Cl}$ depleted in aged sea salt aerosols $\left(\mathrm{Cl}_{\text {depletion }}^{-} \%\right)$, relative acidity, and ionic ratios in each season.

\begin{tabular}{|c|c|c|c|c|}
\hline & $3.2-5.6 \mu \mathrm{m}$ & $5.6-10 \mu \mathrm{m}$ & $10-18 \mu \mathrm{m}$ & $>18 \mu \mathrm{m}$ \\
\hline \multicolumn{5}{|l|}{ Spring } \\
\hline${ }^{1} \mathrm{Cl}_{\text {depletion }}^{-} \%$ & 68.73 & 42.82 & 34.58 & 39.34 \\
\hline${ }^{2}$ Relative acidity & 1.42 & 1.26 & 1.28 & 1.30 \\
\hline$\left(\left[\mathrm{Cl}^{-}\right]+\left[\mathrm{NO}_{3}^{-}\right]\right) /\left[\mathrm{Na}^{+}\right]$ & 1.26 & 1.38 & 1.35 & 1.21 \\
\hline \multicolumn{5}{|l|}{ Summer } \\
\hline $\mathrm{Cl}_{\text {depletion }}^{-} \%$ & 53.76 & 34.57 & 28.28 & 30.81 \\
\hline Relative acidity & 1.22 & 1.21 & 1.33 & 1.41 \\
\hline$\left(\left[\mathrm{Cl}^{-}\right]+\left[\mathrm{NO}_{3}^{-}\right]\right) /\left[\mathrm{Na}^{+}\right]$ & 1.20 & 1.36 & 1.39 & 1.34 \\
\hline \multicolumn{5}{|l|}{ Fall } \\
\hline $\mathrm{Cl}_{\text {depletion }}^{-} \%$ & 51.04 & 28.49 & 18.50 & 6.27 \\
\hline Relative acidity & 1.05 & 1.07 & 1.00 & 1.06 \\
\hline$\left(\left[\mathrm{Cl}^{-}\right]+\left[\mathrm{NO}_{3}^{-}\right]\right) /\left[\mathrm{Na}^{+}\right]$ & 1.20 & 1.29 & 1.34 & 1.42 \\
\hline \multicolumn{5}{|l|}{ Winter } \\
\hline $\mathrm{Cl}_{\text {depletion }}^{-} \%$ & 47.24 & 29.06 & 18.81 & 29.67 \\
\hline Relative acidity & 1.16 & 1.15 & 1.16 & 1.17 \\
\hline$\left(\left[\mathrm{Cl}^{-}\right]+\left[\mathrm{NO}_{3}^{-}\right]\right) /\left[\mathrm{Na}^{+}\right]$ & 1.88 & 1.53 & 1.55 & 1.41 \\
\hline
\end{tabular}

$\mathrm{CO}$ concentrations were observed to be higher in winter and lower in summer (Fig. S7 in the Supplement), consistent with the seasonal pattern of pollutants transported from outside $\mathrm{HK}$ to this site. Therefore, $\mathrm{CO}$ is used as a tracer for transported pollutants in this study.

The minimum sample size $(N)$ needed for obtaining statistically reliable results by factor analysis is $30+(V+3) / 2$, where $V$ is the number of input species (Henry et al., 1984). In order to reduce the input variables, data from adjacent size bins were grouped together, reducing the input sizesegregated data to the following five size categories: (1) $0.056-0.32 \mu \mathrm{m}$; (2) $0.32-0.56 \mu \mathrm{m}$; (3) $0.56-1.0 \mu \mathrm{m}$; (4) $1.0-$ $3.2 \mu \mathrm{m}$; and $(5)>3.2 \mu \mathrm{m}$. The data set of 8 measured variables $\times 43$ samples was then organized as input matrix for PMF analysis. The uncertainty prepared for PMF analysis was set as the sum of analytical uncertainty and one-third of the detection limit for lumped sulfate species (Reff et al., 2007) and $30 \%$ of the corresponding concentration for $\mathrm{CO}$, $\mathrm{SO}_{2}$ and $\mathrm{O}_{\mathrm{x}}$. Three-to-five factors were tested in PMF analysis and the three-factor solution was found to best explain the sulfate formation (Fig. 6). In the four- and five-factor solutions, sulfate in the size category of $1.0-3.2 \mu \mathrm{m}$ forms a factor without association with any gas tracers, leaving this factor unexplained. Five different seed values were tested and similar results were obtained. The seed value was eventually set at 123 . Bootstrapping on the base solution reported stable results, with $>85$ out of 100 bootstrap factors mapped with those in the based run. Fpeak value from -0.5 to 0.5 was examined. Positive Fpeak values were applied to sharpen the $\mathbf{F}$ matrix and to achieve cleaner source profiles. $Q$ values (the objective function for PMF model optimization) as a function of Fpeak values are plotted in Fig. S8a in the Supplement. An examination of source profiles shows the application of Fpeak of 0.1 gives the best result.

The first factor consists of all sulfate in the size range of $0.056-0.32 \mu \mathrm{m}, 72 \%$ of sulfate in the size bin of $0.32-$ $0.56 \mu \mathrm{m}, 48 \%$ of $\mathrm{SO}_{2}$ and $66 \%$ of $\mathrm{O}_{\mathrm{x}}$. Particles in the size bin of $0.056-0.32 \mu \mathrm{m}$ are associated with the condensation process. The abundant presence of sulfate in this size bin indicates that this factor is associated with freshly formed aerosols. The reaction of $\mathrm{SO}_{2}$ with the $\mathrm{OH}$ radical was the major pathway of sulfate formation in the gas phase while $\mathrm{H}_{2} \mathrm{O}_{2}$ is the dominant oxidant for $\mathrm{SO}_{2}$ oxidation in the aqueous phase (Seinfeld and Pandis, 2006; Miyakawa et al., $2007)$. The ratio $\left[\mathrm{SO}_{4}^{2-}\right] /\left(\left[\mathrm{SO}_{2}\right]+\left[\mathrm{SO}_{4}^{2-}\right]\right)$ is calculated to be 0.30 , close to the sulfate conversion extent near power plant sources (Wilson, 1981). This further supports the association of this factor with the freshly formed sulfate particles.

The second factor accounts for more than $60 \%$ of sulfate in the size from 0.56 to $3.2 \mu \mathrm{m}$ and nearly $100 \%$ of CO. The conversion factor of $\mathrm{SO}_{2}$ to sulfate in this factor is 0.97 , much larger than that in the first factor. It is noted that nearly all the sulfate in the size range of $1.0-3.2 \mu \mathrm{m}$ is associated with this factor. A close examination of the size distribution of sulfate 

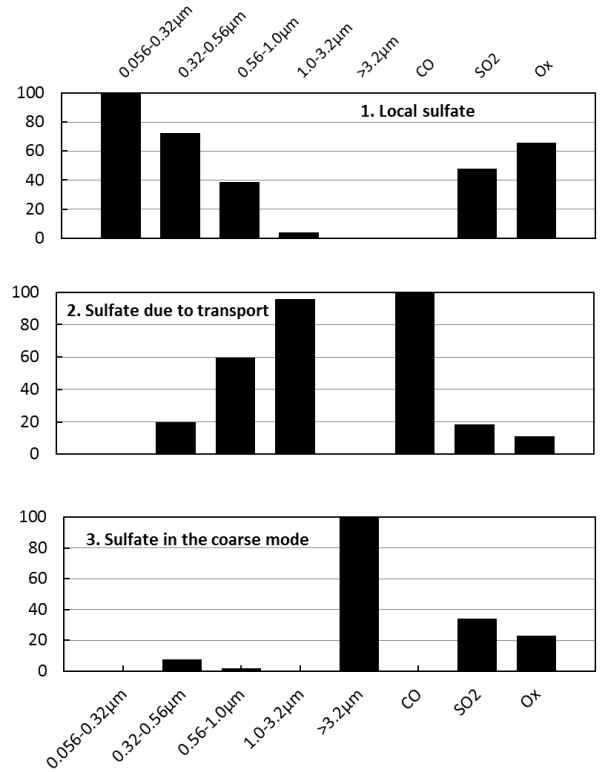

Figure 6. PMF-resolved source profiles (percentage of total species) for size-segregated $\mathrm{SO}_{4}^{2-}$.

(top row in Fig. 2a) indicates that the droplet mode of sulfate was broad and dominant, encompassing most of the sulfate in the 1.0-3.2 $\mu \mathrm{m}$ range. The abundant presence of the supermicron droplet-mode sulfate particles suggests a major contribution from aged air masses, which makes possible significant growth in particle size (Guo et al., 2010). These characteristics indicate that this factor is associated with aged sulfate, i.e., sulfate transported from outside HK.

Nearly all of particulate sulfate on particles $>3.2 \mu \mathrm{m}$ appeared in the third factor. This factor is therefore identified as sulfate in the coarse mode and its further apportionment to different sources/formation pathways is discussed in the next section.

The sum of apportioned sulfate explains well the ambient sulfate measurements (Fig. 7a). The seasonal average contributions from the three PMF-resolved sources are plotted in Fig. 7b. Locally formed sulfate ranged from 0.11 to $6.7 \mu \mathrm{g} \mathrm{m}^{-3}$ in individual samples with the higher values occurring in the spring and fall $\left(\sim 3.0 \mu \mathrm{g} \mathrm{m}^{-3}\right)$, consistent with the high oxidant potential $\left(\mathrm{O}_{\mathrm{x}}\right)$ during these two seasons (Fig. S7 in the Supplement). Transported sulfate was in the range of $0.10-17 \mu \mathrm{g} \mathrm{m}^{-3}$ in individual samples with the highest seasonal average occurring in spring. The seasonal average of sulfate in the coarse mode ranged from 0.3 to $1.3 \mu \mathrm{g} \mathrm{m}^{-3}$ with the highest value in spring. The annual average contribution was estimated to be $30 \%$ $\left(2.5 \mu \mathrm{g} \mathrm{m}^{-3}\right)$ associated with local oxidation of $\mathrm{SO}_{2}, 59 \%$ $\left(4.9 \mu \mathrm{g} \mathrm{m}^{-3}\right)$ due to sulfate transported from outside $\mathrm{HK}$, and $11 \%\left(0.9 \mu \mathrm{g} \mathrm{m}^{-3}\right)$ sulfate in the coarse mode. In the highsulfate cases (total $\left[\mathrm{SO}_{4}^{2-}\right]>14.4 \mu \mathrm{g} \mathrm{m}^{-3}$, the value corresponding to average +1 standard variation of the whole data
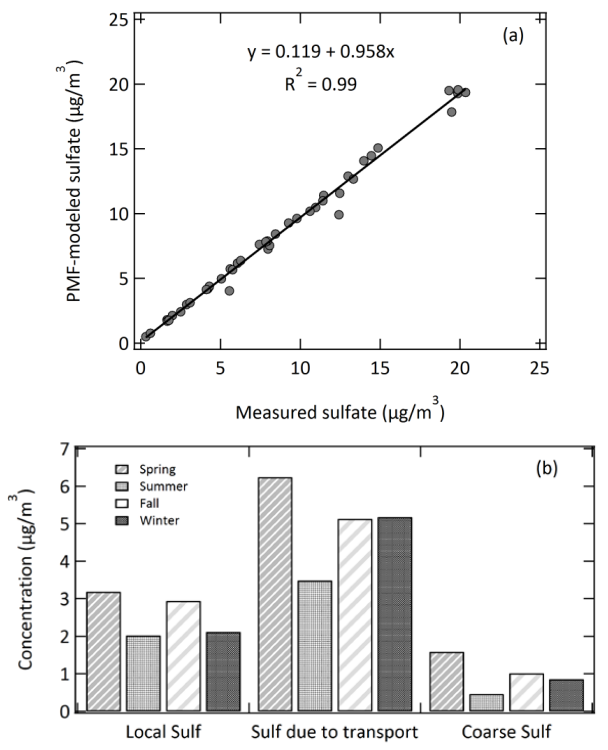

Figure 7. (a) Comparison of PMF-modeled sulfate with the measured sulfate; (b) seasonal variation in contributions of the three sources of sulfate

set), the regional/super-regional pollutant transport played a key role, accounting for an average of $68 \%$ of total sulfate and $78 \%$ of sulfate in fine mode.

\subsubsection{PMF analysis of coarse-mode sulfate}

To further understand the formation pathway and sources of sulfate in the coarse mode, sulfate and other ionic species $\left(\mathrm{Na}^{+}, \mathrm{Mg}^{2+}, \mathrm{NO}_{3}^{-}, \mathrm{Ca}^{2+}, \mathrm{K}^{+}\right.$and $\left.\mathrm{NH}_{4}^{+}\right)$in the coarse mode were organized as input matrix for PMF analysis. $\mathrm{PM}_{2.5} \mathrm{Si}$ as a tracer for bulk soil particles (no coarse Si data available) was also included as input data, as its inclusion significantly improves the agreement of PMF-reconstructed and measured $\mathrm{Ca}^{2+}$ data. Uncertainties for these variables were set as the sum of analytical uncertainty and one-third of detection limit. Fpeak values from -0.5 to 0.5 were examined and zero was chosen for the final solution (Fig. S8b in the Supplement). Four factors were found to reasonably explain the physical meaning of each source (Fig. 8). The seasonal variations in source contributions are shown in Fig. S9 in the Supplement for individual source factors.

Prominent $\mathrm{Na}^{+}, \mathrm{Mg}^{2+}, \mathrm{K}^{+}, \mathrm{Cl}^{-}$and $\sim 13 \%$ of the coarsemode sulfate appear in the first factor. $\mathrm{Na}^{+}, \mathrm{Mg}^{2+}$ and some $\mathrm{K}^{+}$on particles larger than $3.2 \mu \mathrm{m}$ are considered to be the tracers for sea salt particles. Major ions in seawater with salinity of $35 \%$ are $\mathrm{Cl}^{-}(55.29 \%$ in the mass percentage), $\mathrm{Na}^{+}(30.74 \%), \mathrm{Mg}^{2+}(3.69 \%), \mathrm{SO}_{4}^{2-}(7.75 \%), \mathrm{Ca}^{2+}$ $(1.18 \%)$ and $\mathrm{K}^{+}(1.14 \%)$ (Millero and Sohn, 1992). The relative abundance of individual species resolved by PMF in this factor agreed fairly well with that in the seawater except that the PMF-derived $\mathrm{SO}_{4}^{2-}$ was about half of that in the 

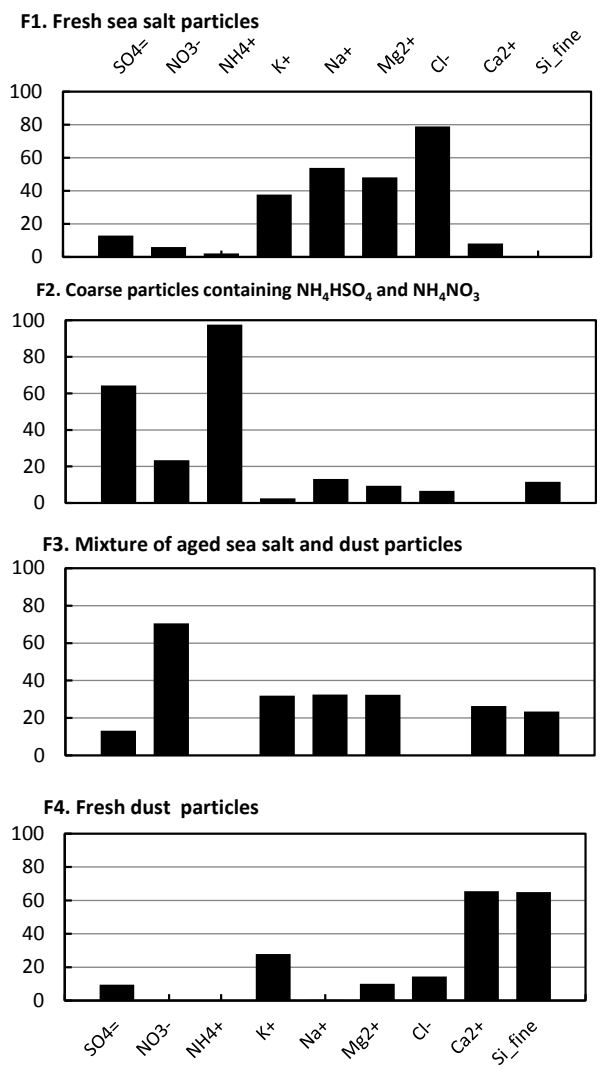

Figure 8. PMF-resolved source profiles (percentage of total species) for coarse-mode data. $\mathrm{PM}_{2.5} \mathrm{Si}$ as a surrogate for bulk dust particles is also included as input data.

seawater (Fig. S10 in the Supplement). This factor therefore was identified as fresh sea salt.

The second factor consists of $98 \%$ of $\mathrm{NH}_{4}^{+}, 64 \%$ of $\mathrm{SO}_{4}^{2-}$, $23 \%$ of $\mathrm{NO}_{3}^{-}, 13 \%$ of $\mathrm{Na}^{+}$, and $11 \%$ of $\mathrm{Si}$. The equivalent ratio of $\mathrm{NH}_{4}^{+}, \mathrm{SO}_{4}^{2-}$, and $\mathrm{NO}_{3}^{-}(1.5: 1.0: 1.0)$ in this factor indicates that sulfate mainly exists as $\mathrm{NH}_{4} \mathrm{HSO}_{4}$ and nitrate as $\mathrm{NH}_{4} \mathrm{NO}_{3}$. The alkaline species (i.e., $\mathrm{Ca}^{2+}, \mathrm{Mg}^{2+}$, and $\mathrm{Na}^{+}$) in dust and sea salt make it difficult for ammonia to partition into dust and sea salt particles (Xu and Penner, 2012). Considering the abundant presence of $\mathrm{NH}_{4}^{+}$in this factor, we therefore attribute coarse-mode sulfate apportioned to this factor (termed as $\left[\mathrm{SO}_{4}^{2-}\right]_{\mathrm{C} \_ \text {F2 }}$ hereafter) to coagulation of fine $\mathrm{NH}_{4} \mathrm{HSO}_{4}$ and $\mathrm{NH}_{4} \mathrm{NO}_{3}$ particles with coarse sea salt/dust particles or resuspension of dust particles that contain $\mathrm{NH}_{4} \mathrm{HSO}_{4}$ and $\mathrm{NH}_{4} \mathrm{NO}_{3}$, the presence of which in dust could come from dry or wet deposition of ambient aerosols. As $\mathrm{Ca}^{2+}$ in the smaller coarse mode (i.e., $\left[\mathrm{Ca}^{2+}\right]_{\mathrm{CMI}}$ ) represents long-range-transported dust particles, an association between $\left[\mathrm{SO}_{4}^{2-}\right]_{\mathrm{C}_{-} \mathrm{F} 2}$ and $\left[\mathrm{Ca}^{2+}\right]_{\mathrm{CMI}}$ is anticipated if coagulation of $\mathrm{NH}_{4} \mathrm{HSO}_{4}$ fine particles is a significant source for $\left[\mathrm{SO}_{4}^{2-}\right]_{\mathrm{C} \_\mathrm{F} 2}$. However, an association between $\left[\mathrm{SO}_{4}^{2-}\right]_{\mathrm{C} \_\mathrm{F} 2}$ and $\mathrm{Ca}^{2+}$ in coarse-mode II (i.e., $\left[\mathrm{Ca}^{2+}\right]_{\mathrm{CMII}}$ ) is expected if resuspension of dust particles is a significant source for
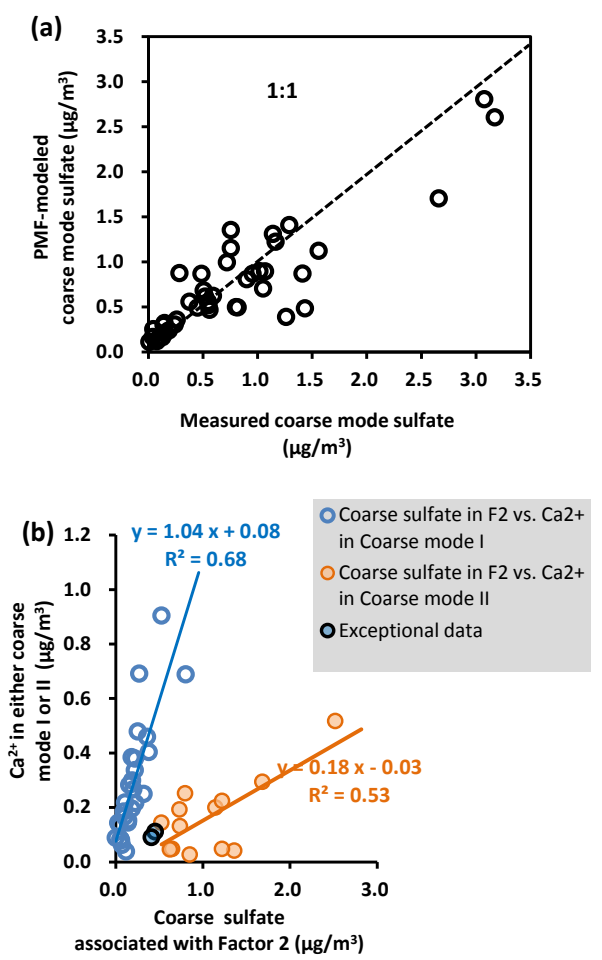

Figure 9. (a) Total sulfate in the coarse mode versus PMF-model estimated sulfate. (b) Relationship of coarse-mode sulfate apportioned to the $\mathrm{NH}_{4} \mathrm{HSO}_{4}$-containing coarse particles (i.e., Factor 2) with $\mathrm{Ca}^{2+}$ concentration in either coarse-mode I (blue open circles) or coarse-mode II (yellow filled circles). There are two exceptional data (filled circles with blank outline) that do not fit in either of the two groups.

$\left[\mathrm{SO}_{4}^{2-}\right]_{\mathrm{C}_{-} \mathrm{F} 2}$. We next examine correlations of $\left[\mathrm{SO}_{4}^{2-}\right]_{\mathrm{C}_{2} \mathrm{~F} 2}$ with $\left[\mathrm{Ca}^{2+}\right]_{\mathrm{CMI}}$ and $\left[\mathrm{Ca}^{2+}\right]_{\mathrm{CMII}}$. It is found that the samples fall into two groups. For samples with lower $\left[\mathrm{SO}_{4}^{2-}\right]_{\mathrm{C}_{-} \mathrm{F} 2}$ (roughly $<0.4 \mu \mathrm{g} \mathrm{m}^{-3}, n=28$ ), $\left[\mathrm{SO}_{4}^{2-}\right]_{\text {C_F2 }}$ strongly correlates with $\left[\mathrm{Ca}^{2+}\right]_{\mathrm{CMI}}\left(R^{2}=0.68\right)($ Fig. $9 \mathrm{~b})$ while the correlation with $\left[\mathrm{Ca}^{2+}\right]_{\mathrm{CMII}}$ is significantly weaker $\left(R^{2}=0.49\right)$. For

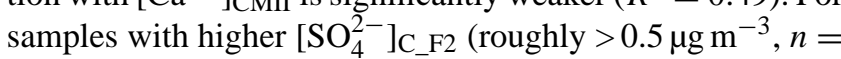
$13)$, however, a moderate positive correlation $\left(R^{2}=0.53\right.$, Fig. 9b) exists between $\left[\mathrm{SO}_{4}^{2-}\right]_{\mathrm{C}_{-} \mathrm{F} 2}$ and $\left[\mathrm{Ca}^{2+}\right]_{\mathrm{CMII}}$ while the correlation with $\left[\mathrm{Ca}^{2+}\right]_{\mathrm{CMI}}$ is much weaker $\left(R^{2}=0.23\right)$. The correlation results indicate that both the coagulation process and resuspended dust particles could be significant sources for $\left[\mathrm{SO}_{4}^{2-}\right]_{\mathrm{C} \_F 2}$. That PMF failed to resolve these two sources is most likely due to the limited number of sample sizes.

The third factor is characterized by the abundant presence of nitrate, $\mathrm{Ca}^{2+}, \mathrm{Si}$ and chloride-depleted sea salt species $\left(\mathrm{Na}^{+}, \mathrm{Mg}^{2+}\right.$, and $\left.\mathrm{K}^{+}\right)$. Heterogeneous reactions of sulfuric acid and nitric acid on sea salt or dust particles (e.g., Reactions R2 and R4) are mainly responsible for this source of coarse-mode sulfate. The covariation of nitrate and chloridedepleted sea salt species suggested the existence of Reaction $\mathrm{R} 2$; i.e., chloride in the sea salt was replaced by nitrate in 
the polluted atmosphere over certain period. $\mathrm{Ca}^{2+}$ and $\mathrm{Si}$ are the tracers for dust, which may be amalgamated with local aged sea salt after long-range transport. This factor was thus identified as the mixture of aged sea salt and dust particles.

The fourth factor is identified as fresh dust particles that have not undergone atmospheric processing (such as acidification), as this factor is characterized with abundant $\mathrm{Si}$ and $\mathrm{Ca}^{2+}$ but little sulfate and absence of nitrate.

The comparisons of PMF-reconstructed and measured coarse-mode concentrations show $R^{2}$ values of linear regression better than 0.95 for $\mathrm{NO}_{3}^{-}, \mathrm{Cl}^{-}, \mathrm{NH}_{4}^{+}, \mathrm{Na}^{+}$, and $\mathrm{Mg}^{2+}$, and 0.83 for $\mathrm{Ca}^{2+}$ (Table $\mathrm{S} 2$ in the Supplement). The agreement for coarse sulfate $\left(R^{2}=0.79\right)$ is weaker but still reasonable (Fig. 9a). This result indicates that the PMF solution captures most of the variation in the coarse-mode sulfate while it also suggests that it is likely there are sources or processes not properly represented by the input species. The small sample size and lack of direct coarse dust particle tracer data may be the contributing causes for the limitation in the PMF solution for the coarse sulfate.

The PMF results show that on average two-thirds of coarse sulfate is $\mathrm{NH}_{4} \mathrm{HSO}_{4}$-containing coarse particles $\left(\sim 0.5 \mu \mathrm{g} \mathrm{m}^{-3}\right)$ while the other three sources (i.e., sea salt sulfate, dust sulfate, and aged sea salt/dust particles) make comparable contributions to the remaining one-third of coarse sulfate.

\section{Summary and implications}

Size distributions of nine ionic species $\left(\mathrm{SO}_{4}^{2-}, \mathrm{NO}_{3}^{-}, \mathrm{Cl}^{-}\right.$, $\mathrm{C}_{2} \mathrm{O}_{4}^{2-}, \mathrm{Na}^{+}, \mathrm{NH}_{4}^{+}, \mathrm{K}^{+}, \mathrm{Mg}^{2+}$, and $\mathrm{Ca}^{2+}$ ) were determined in a total of 43 sets of samples collected at a suburban receptor location over a year. $\mathrm{SO}_{4}^{2-}, \mathrm{NH}_{4}^{+}, \mathrm{C}_{2} \mathrm{O}_{4}^{2-}$ and $\mathrm{K}^{+}$mainly resided in the droplet mode with MMAD of 0.7-0.9 $\mu \mathrm{m}$. Minor volatilization and repartition of $\mathrm{C}_{2} \mathrm{O}_{4}^{2-}$ led to a larger MMAD and a broader size distribution for the droplet mode under conditions of higher temperatures (i.e., over $22^{\circ} \mathrm{C}$ ). Two coarse modes and one droplet mode were inverted for the species associated with sea salt and dust particles, with the MMADs of the two coarse modes as $2-4$ and $6-8 \mu \mathrm{m}$, respectively. The smaller coarse mode for $\mathrm{Ca}^{2+}$ was likely associated with long-range-transported dust particles while the larger coarse mode is mainly associated with locally produced soil particles. The seasonal variation of ambient sea salt concentrations could be caused by the seasonal fluctuation in the marine salinity. Modifications of the parameterization of sea salt emissions and the oceanic salinity in the air quality models are needed in order to improve the model performance.

As a result of interacting with sea salt and dust particles, $\mathrm{NO}_{3}^{-}$was generally dominated by the coarse mode. The enhanced presence of nitrate in fine mode was observed on winter days with lower temperatures and on days with lower concentrations of sea salt and soil particles. An inversely proportional relationship was established using the data set between the fraction of nitrate in the fine mode and $\left(1 /\left[\mathrm{Na}^{+}\right]+2\left[\mathrm{Ca}^{2+}\right]\right) \times\left(1 / K_{e}^{\prime}\right)$; i.e., the product of the sum of alkaline ions in equivalent concentrations $\left(\mathrm{Na}^{+}\right.$and $\mathrm{Ca}^{2+}$ ) and the modified dissociation constant of ammonium nitrate. This relationship explains the variable characteristics in nitrate-size distribution. Due to the limited sample size and sampling artifact of nitrate, more measurements are needed to further study the relationship.

The local formation and transport contribution of sulfate were estimated by applying PMF analysis on the combined data sets of size-segregated sulfate and select gaseous air pollutants $\left(\mathrm{SO}_{2}, \mathrm{O}_{\mathrm{x}}\right.$ and $\left.\mathrm{CO}\right)$. The regional/super-regional source dominated the observed sulfate at HKUST, especially on high-sulfate days. On average, the regional source contributed $59 \%\left(4.9 \mu \mathrm{g} \mathrm{m}^{-3}\right)$ while the locally formed sulfate accounted for $30 \%\left(2.5 \mu \mathrm{g} \mathrm{m}^{-3}\right)$, and the remaining sulfate $\left(0.9 \mu \mathrm{g} \mathrm{m}^{-3}\right)$ was on coarse-mode particles. Further PMF analysis of the coarse-mode chemical composition data suggests that most of the coarse-mode sulfate were contributed by $\mathrm{NH}_{4} \mathrm{HSO}_{4}$-containing coarse particles. This source of coarse sulfate was its origin in fine $\mathrm{NH}_{4} \mathrm{HSO}_{4}$ particles, which shifted to the coarse mode through coagulation and/or deposition followed by resuspension. Results from this study demonstrate the importance of understanding both local photochemistry and regional/super-regional transport in order to properly model sulfate aerosols.

\section{The Supplement related to this article is available online at doi:10.5194/acp-14-9013-2014-supplement.}

Acknowledgements. This work was supported by the Environmental Conservation Funds (ECF) of Hong Kong (ECWW09EG04). We thank the Hong Kong Environmental Protection Department for making available the MARGA data and Alexis Lau for the criteria gas monitoring data. Bian Q. also thanks Liu Zhiqiang for the valuable discussion of possible factors driving atmospheric sea salt particulate variability in Hong Kong.

Edited by: Y. Cheng

\section{References}

Allen, A. G., Cardoso, A. A., and da Rocha, G. O.: Influence of sugar cane burning on aerosol soluble ion composition in Southeastern Brazil, Atmos. Environ., 38, 5025-5038, 2004.

Andreas, E. L.: A new sea spray generation function for wind speeds up to $32 \mathrm{~m} \mathrm{~s}^{-1}$, J. Phys. Oceanogr., 28, 2175-2184, 1998.

Carlton, A. G., Turpin, B. J., Altieri, K. E., Seitzinger, S., Reff, A., Lim, H.-J., and Ervens, B.: Atmospheric oxalic acid and SOA production from glyoxal: Results of aqueous photooxidation experiments, Atmos. Environ., 41, 7588-7602, 2007. 
Chang, M. C., Sioutas, C., Kim, S., Gong, H., and Linn, W. S.: Reduction of nitrate losses from filter and impactor samplers by means of concentration enrichment, Atmos. Environ., 34, 85-98, 2000.

Dong, Y., Hays, M. D, Smith, N. D., and Kinsey, J. S.: Inverting cascade imparctor data for size-resolved characterization of fine partculate source emissions, J. Aerosol Sci., 35, 1497-1512, 2004

Duan, J. C., Bi, X. H., Tan, J. H., Sheng, G. Y., and Fu, J. M.: The differences of the size distribution of polycyclic aromatic hydrocarbons (PAHs) between urban and rural sites of Guangzhou, China, Atmos. Res., 78, 190-203, 2005.

Dzubay, T. G. and Hasan, H.: Fitting multimodal lognormal size distributions to Cascade Impactor data, Aerosol Sci. Technol., 13, 144-150, 1990.

Gan, J. P., Cheung, A., Guo, X. G., and Li, L.: Intensified upwelling over a widened shelf in the northeastern South China Sea, J. Geophys. Res., 114, C09019, doi:10.1029/2007JC004660, 2009.

Guan, B. X. and Fang, G. H.: Winter counter-wind currents off the southeastern China coast: A review, J. Oceanogr. 62, 1-24, 2006.

Guo, S., Hu, M., Wang, Z. B., Slanina, J., and Zhao, Y. L.: Sizeresolved aerosol water-soluble ionic compositions in the summer of Beijing: implication of regional secondary formation, Atmos. Chem. Phys., 10, 947-959, doi:10.5194/acp-10-947-2010, 2010.

Harrison, R. M. and Pio, C. A.: Size-cifferentiated composition of inorganic atmospheric aerosols of both marine and polluted continental origin, Atmos. Environ., 17, 1733-1738, 1983.

Henry, R. C., Lewis, C. W., Hopke, P. K., and Williamson, H. J.: Review of receptor model fundamentals, Atmos. Environ., 18, 1507-1515, 1984.

Howell, S., Pszenny, A. A. P., Quinn, P., and Huebert, B.: A field intercomparison of three cascade impactors, Aerosol Sci. Technol., 29, 475-492, 1998.

He, L.-Y., Huang, X.-F., Xue, L., Hu, M., Lin, Y., Zheng, J., Zhang, R., and Zhang, Y.-H.: Submicron aerosol analysis and organic source apportionment in an urban atmosphere in Pearl River Delta of China using high-resolution aerosol mass spectrometry, J. Geophys. Res.-Atmos., 116, D12304, doi:10.1029/2010JD014566, 2011.

Huang, X. F., Yu, J. Z., He, L. Y., and Yuan, Z. B.: Watersoluble organic carbon and oxalate in aerosols at a coastal urban site in China: Size distribution characteristics, sources, and formation mechanisms, J. Geophys. Res.-Atmos., 111, D22212, doi:10.1029/2006JD007408, 2006.

Huang, X. H. H., Bian, Q., Ng, W. M., Louie, P. K. K., and Yu, J. Z.: Characterization of $\mathrm{PM}_{2.5}$ major components and source investigation in suburban Hong Kong: a one year monitoring study, Aerosol Air Qual. Res., 14, 237-250, 2014a.

Huang, X. H. H., Bian, Q. J., Louie, P. K. K., and Yu, J. Z.: Contributions of vehicular carbonaceous aerosols to $\mathrm{PM}_{2.5}$ in a roadside environment in Hong Kong, Atmos. Chem. Phys. Discuss., 14, 57-93, doi:10.5194/acpd-14-57-2014, 2014b.

Husar, R. B.: Intercontinental transport of dust: historical and recent observational evidence, Springer Verlag, chapter 11, 2004.

Kelly, J. T., Bhave, P. V., Nolte, C. G., Shankar, U., and Foley, K. M.: Simulating emission and chemical evolution of coarse seasalt particles in the Community Multiscale Air Quality (CMAQ) model, Geosci. Model Dev., 3, 257-273, doi:10.5194/gmd-3257-2010, 2010.
Kim, E., Hopke, P. K., Larson, T. V., and Covert, D. S.: Analysis of ambient particle size distributions using unmix and positive matrix factorization, Environ. Sci. Technol., 38, 202-209, 2004.

Kundu, S., Kawamura, K., Andreae, T. W., Hoffer, A., and Andreae, M. O.: Molecular distributions of dicarboxylic acids, ketocarboxylic acids and $\alpha$-dicarbonyls in biomass burning aerosols: implications for photochemical production and degradation in smoke layers, Atmos. Chem. Phys., 10, 2209-2225, doi:10.5194/acp-10-2209-2010, 2010.

Lan, Z. J., Chen, D. L., Li, X., Huang, X. F., He, L. Y., Deng, Y. G., Feng, N., and Hu, M.: Modal characteristics of carbonaceous aerosol size distribution in an urban atmosphere of South China, Atmos. Res., 100, 51-60, 2011.

Lee, Y. C., Yang, X., and Wenig, M.: Transport of dusts from East Asian and non-East Asian sources to Hong Kong during dust storm related events 1996-2007, Atmos. Environ., 44, 37283738, 2010.

Limbeck, A., Puxbaum, H., Otter, L., and Scholes, M. C.: Semivolatile behavior of dicarboxylic acids and other polar organic species at a rural background site (Nylsvley, RSA), Atmos. Environ., 35, 1853-1862, 2001.

Liu, S., Hu, M., Slanina, S., He, L. Y., Niu, Y. W., Bruegemann, E., Gnauk, T., and Herrmann, H.: Size distribution and source analysis of ionic compositions of aerosols in polluted periods at Xinken in Pearl River Delta (PRD) of China, Atmos. Environ., 42, 6284-6295, 2008.

Louie, P. K. K., Wastson, J. G., Chow, J. C., Chen, A., Sin, D. W. M., and Lau, A. K. H.: Seasonal characteristics and regional transport of $\mathrm{PM}_{2.5}$ in Hong Kong, Atmos. Environ., 29, 1695-1710, 2005.

Meng, Z. Y. and Seinfeld, J. H.: On the source of the submicrometer droplet mode of urban and regional aerosols., Aerosol Sci. Technol., 20, 253-265, 1994.

Millero, F. J. and Sohn, M. J.: Chemistry Oceanography, CRC Press, Boca Raton, FL, 1992.

Miyakawa, T., Takegawa, N., and Kondo, Y.: Removal of sulfur dioxide and formation of sulfate aerosol in Tokyo, J. Geophys. Res.-Atmos., 112, D13209, doi:10.1029/2006JD007896, 2007.

Mochida, M., Umemoto, N., Kawamura, K., and Uematsu, M.: Bimodal size distribution of $\mathrm{C}_{2}-\mathrm{C}_{4}$ dicarboxylic acids in the marine aerosols, Geophys. Res. Lett., 30, 1672, doi:10.1029/2003GL017451, 2003.

Mozurkewich, M.: The dissociation-constant of ammonium-nitrate and its dependence on temperature, relative-humidity and particle-size, Atmos. Environ., 27A, 261-270, 1993.

Pakkanen, T. A., Kerminen, V. M., Hillamo, R. E., Makinen, M., Makela, T., and Virkkula, A.: Distribution of nitrate over sea-salt and soil derived particles - Implications from a field study, J. Atmos. Chem., 24, 189-205, 1996.

Reff, A., Eberly, S. I., and Bhave, P. V.: Receptor modeling of ambient particulate matter data using positive matrix factorization: review of existing methods, J. Air Waste Manage. Assoc. 57, 146154, 2007.

Rindaldi, M., Decesari, S., Carbone, C., and Tsigaridis, K. Evidence of a natural marine source of oxalic acid and a possible link to glyoxal, J. Geophys. Res., 116, D16204, doi:10.1029/2011JD015659, 2011.

Rogge, W. F., Hildemann, L. M., Mazurek, M. A., Cass, G. R., and Simonelt, B. R. T.: Sources of fine organic aerosol, 1. Char- 
broilers and meat cooking operations, Environ. Sci. Technol., 25, 1112-1125, 1991.

Seinfeld, J. H. and Pandis, S. N.: Atmospheric Chemistry and Physics - From Air Pollution to Climate Change (2nd Edn.), John Wiley \& Sons, the United State of America, p. 311, p. 477, 2006.

Stein, S. W., Turpin, B. J., Cai, X. P., Huang, C. P. F., and Mcmurry, P. H.: Measurements of relative humidity-dependent bounce and density for atmospheric particles using the DMA-impactor technique, Atmos. Environ., 28, 1739-1746, 1994.

Stelson, A. W. and Seinfeld, J. H.: Thermodynamic prediction of the water activity, $\mathrm{NH}_{4} \mathrm{NO}_{3}$ dissociation-constant, density and refractive-index for the $\mathrm{NH}_{4} \mathrm{NO}_{3}-\left(\mathrm{NH}_{4}\right)_{2} \mathrm{SO}_{4}-\mathrm{H}_{2} \mathrm{O}$ System at $25^{\circ} \mathrm{C}$, Atmos. Environ., 16, 2507-2514, 1982.

Sullivan, R. C. and Prather, K. A.: Investigations of the diurnal cycle and mixing state of oxalic acid in individual particles in Asian Aerosol outflow, Environ. Sci. Technol., 41, 8062-8069, 2007.

Thiyagarajan, V., Harder, T., and Qian, P. Y.: Effect of the physiological condition of cyprids and laboratory-mimicked seasonal conditions on the metamorphic successes of Balanus amphitrite Darwin (Cirripedia; Thoracica), J. Exp. Mar. Biol. Ecol., 274, 65-74, 2002.

Twomey, S.: Comparison of constrained linear inversion and an iterative nonlinear algorithm applied to indirect estimation of particle-size distributions, J. Comput. Phys., 18, 188-200, 1975.

VanCuren, R. A., Cliff, S. S., Perry, K. D., and Jimenez-Cruz, M.: Asian continental aerosol persistence above the marine boundary layer over the eastern North Pacific: Continous aeroso measurements from Intercontinental Transport and Chemical Transformation 2002 (ITCT 2K2), J. Geophys. Res.-Atmos., 110, D09S90, doi:10.1029/2004JD004973, 2005.

van Pinxteren, D., Neusüß, C., and Herrmann, H.: On the abundance and source contributions of dicarboxylic acids in sizeresolved aerosol particles at continental sites in central Europe, Atmos. Chem. Phys., 14, 3913-3928, doi:10.5194/acp-14-39132014, 2014.

Wai, K. M. and Tanner, P. A.: Wind-dependent sea salt aerosol in a Western Pacific coastal area, Atmos. Environ., 38, 1167-1171, 2004.

Warneck, P.: In-cloud chemistry opens pathway to the formation of oxalic acid in the marine atmosphere, Atmos. Environ., 37, 2423-2427, 2003.

Wilson, W. E.: Sulfate formation in point source plumes: A review of recent field studies, Atmos. Environ., 15, 2573-2581, 1981.

Winklmayr, W., Wang, H. C., and John, W.: Adaptation of the twomey algorithm to the inversion of cascade impactor data, Aerosol Sci. Technol., 13, 322-331, 1990.

Wu, D.: Numerical study of atmospheric particulate matters: source apportionment to characterize 3D transport and transformation of precursors and secondary pollutants, Ph.D. thesis, Hong Kong University of Science \& Technology, 2013.

Xu, L. and Penner, J. E.: Global simulations of nitrate and ammonium aerosols and their radiative effects, Atmos. Chem. Phys., 12, 9479-9504, doi:10.5194/acp-12-9479-2012, 2012.

Xue, J., Yuan, Z., Yu, J. Z., and Lau, A. K. H.: An observation-based model for secondary inorganic aerosols, Aerosol Air Qual. Res., 14, 862-878, 2014.
Yang, F., Tan, J., Zhao, Q., Du, Z., He, K., Ma, Y., Duan, F., Chen, G., and Zhao, Q.: Characteristics of $\mathrm{PM}_{2.5}$ speciation in representative megacities and across China, Atmos. Chem. Phys., 11, 5207-5219, doi:10.5194/acp-11-5207-2011, 2011.

Yang, H., Yu, J. Z., Ho, S. S. S., Xu, J., Wu, W.-S., Wan, C. H., Wang, X., Wang, X., and Wang, L., The chemical compostion of inorganic and carbonaceous materials in $\mathrm{PM}_{2.5}$ in Nanjing, China, Atmos. Environ., 39, 3735-2749, 2005.

Yao, X. H. and Zhang, L. M.: Chemical processes in sea-salt chloride depletion observed at a Canadian rural coastal site, Atmos. Environ., 46, 189-194, 2012.

Yao, X. H., Fang, M., and Chan, C. K.: Size distributions and formation of dicarboxylic acids in atmospheric particles, Atmos. Environ., 36, 2099-2107, 2002.

Yao, X. H., Fang, M., and Chan, C. K.: The size dependence of chloride depletion in fine and coarse sea-salt particles, Atmos. Environ., 37, 743-751, 2003.

Yoshizumi, K. and Hoshi, A.: Size distributions of ammoniumnitrate and sodium-nitrate in atmospheric aerosols, Environ. Sci. Technol., 19, 258-261, 1985.

Yu, H., Wu, C., Wu, D., and Yu, J. Z.: Size distributions of elemental carbon and its contribution to light extinction in urban and rural locations in the pearl river delta region, China, Atmos. Chem. Phys., 10, 5107-5119, doi:10.5194/acp-10-5107-2010, 2010.

Yu, J. Z., Huang, X. F., Xu, J. H., and Hu, M.: When aerosol sulfate goes up, so does oxalate: Implication for the formation mechanisms of oxalate, Environ. Sci. Technol., 39, 128-133, 2005.

Yuan, Z., Yadav, V., Turner, J. R., Louie, P. K. K., and Lau, A. K. H.: Long-term trends of ambient particulate matter emission source contributions and the accountability of control strategies in Hong Kong over 1998-2008, Atmos. Environ., 76, 21-31, 2013.

Yue, D. L., Hu, M., Wu, Z. J., Guo, S., Wen, M. T., Nowak, A., Wehner, B., Wiedensohler, A., Takegawa, N., Kondo, Y., Wang, X. S., Li, Y. P., Zeng, L. M., and Zhang, Y. H.: Variation of particle number size distributions and chemical compositions at the urban and downwind regional sites in the Pearl River Delta during summertime pollution episodes, Atmos. Chem. Phys., 10, 9431-9439, doi:10.5194/acp-10-9431-2010, 2010.

Zhang, H., Li, J., Ying, Q., Yu, J. Z., Wu, D., Cheng, Y., He, K., and Jiang, J.: Source apportionment of $\mathrm{PM}_{2.5}$ nitrate and sulfate in China using a source-oriented chemical transport model, Atmos. Environ., 62, 228-242, 2012.

Zhou, L., Kim, E., Hopke, P. K., Stainier, C., and Pandis, S. N.: Advanced factor analysis on Pittsburgh particle size distribution data, Aerosol Sci. Technol., 38, 118-132, 2004.

Zhou, L., Hopke, P. K., Stainer, C. O., Pandis, S. N., Ondov, J. M., and Pancras, J. P.: Investigation of the relationship between chemical composition and size distribution of airborne particles by partial least squares and positive matrix factorization, J. Geophys. Res.-Atmos., 110, D07S18, doi:10.1029/2004JD005050, 2005.

Zhuang, H., Chan, C. K., Fang, M., and Wexler, A. S.: Formation of nitrate and non-sea-salt sulfate on coarse particles, Atmos. Environ., 33, 4223-4233, 1999a.

Zhuang, H., Chan, C. K., Fang, M., and Wexler, A. S.: Size distributions of particulate sulfate, nitrate, and ammonium at a coastal site in Hong Kong, Atmos. Environ., 33, 843-853, 1999b. 